\title{
The Anticancer Potential of Maslinic Acid and Its Derivatives: A Review
}

\author{
Lei $\mathrm{Yu}^{\mathrm{l}, *}$ \\ Xiaofang $\mathrm{Xie}^{1, *}$ \\ Xiaoyu Cao' \\ Junren Chen' \\ Guanru Chen' \\ Yan Chen' \\ Gangmin $\mathrm{Li}^{1}$ \\ Junyuan $\operatorname{Qin}^{\prime}$ \\ Fu Peng ${ }^{2}$ \\ Cheng Peng (D)
}

'State Key Laboratory of Southwestern Chinese Medicine Resources, Chengdu University of Traditional Chinese Medicine, Chengdu, People's Republic of China; ${ }^{2}$ Department of Pharmacology, Key Laboratory of Drug-Targeting and Drug Delivery System of the Education Ministry, Sichuan Engineering Laboratory for PlantSourced Drug and Sichuan Research Center for Drug Precision Industrial Technology, West China School of Pharmacy, Sichuan University, Chengdu, 61004I, People's Republic of China

*These authors contributed equally to this work

Correspondence: Fu Peng

Department of Pharmacology, Key

Laboratory of Drug-Targeting and Drug

Delivery System of the Education

Ministry, Sichuan Engineering Laboratory

for Plant-Sourced Drug and Sichuan

Research Center for Drug Precision

Industrial Technology, West China School

of Pharmacy, Sichuan University, Chengdu,

6I004I, People's Republic of China

$\mathrm{Tel} / \mathrm{Fax}+86$ 28-618000I8

Email fujing |26@yeah.net

Cheng Peng

State Key Laboratory of Southwestern

Chinese Medicine Resources, Chengdu

University of Traditional Chinese

Medicine, Chengdu, 6III37, People's

Republic of China

Tel/Fax +86 28-6I80023I

Email cdtcmpengcheng@I26.com

\begin{abstract}
Cancer is still an insurmountable problem for humans and critically attacking human health. In recent years, natural products have gained increasing attention in the field of anti-tumor due to their extensive sources and minimal side effects. Maslinic acid (MA), a pentacyclic triterpene acid mainly derived from the olive tree (Olea europaea L.) has been confirmed to possess great anti-cancer effects. This paper reviewed the inhibitory effect of MA and its derivatives on lung cancer, colon cancer, ovarian cancer, gastric cancer, lymphatic, leukemia, breast cancer, pancreatic cancer, melanoma, prostate cancer, renal cell carcinoma, gallbladder cancer, and bladder cancer, among others. MA inhibited the proliferation of various tumor cells and showed lower $\mathrm{IC}_{50}$ values in melanoma 518A2 cells and gastric cancer MKN28 cells compared with other cell lines. A series of semi-synthetic derivatives obtained by modifying MA chemical structure have been shown to have high cytotoxicity to human tumor cell lines, but low cytotoxicity to nonmalignant cells, which is conducive to developing its potential as a chemotherapeutic agent. These studies suggest that MA derivatives have broad prospects in the development of antitumor therapeutics in the future and warrant further study.
\end{abstract}

Keywords: maslinic acid, tumor, mechanism, derivatives

\section{Introduction}

Cancer, generally characterized by uncontrolled growth and spread of abnormal cells, is the second leading cause of death worldwide, following cardiovascular diseases. ${ }^{1}$ The occurrence of cancer is complex and multi-factorial, which involves excessive oxidative stress, chronic inflammation, cell cycle disorders, abnormal expression of proto-oncogenes, and angiogenesis disorders. ${ }^{2-5}$ Chemotherapy is a primary treatment for cancer. However, due to low selectivity and drug resistance of chemotherapeutic drugs, chemotherapy does not achieve the best possible results. Therefore, finding more effective chemotherapy agent is needed. ${ }^{6,7}$ Natural compounds derived from Traditional Chinese Medicine (TCM), a class of drugs that are widely distributed in nature with many pharmacological applications, have been recognized as a rich source for new drug discovery. ${ }^{8-11}$ According to reports, approximately half of small molecule anti-tumor drugs approved from the 1940s to 2018 were derived from natural products or analogs. ${ }^{12,13}$ Therefore, natural products as promising candidates for anti-cancer treatment have broad application prospects.

Pentacyclic triterpenes are an important class of plant secondary metabolites. Due to their extensive antitumor activity and lack of obvious toxicity, pentacyclic triterpenes are promising leading compounds for developing new multi-targeting 
antitumor agents. ${ }^{14-17}$ Maslinic acid [MA, $(2 \alpha, 3 \beta)$ 2,3-dihydroxylolean-12-en-28-oic acid] (Figure 1) is a pentacyclic triterpene acid primarily derived from the olive tree (Olea europaea L.) and shanzha (Crataegus pinnatifida Bunge), with a $\mathrm{C}_{30} \mathrm{H}_{48} \mathrm{O}_{4}$ molecular formula, molecular weight of 472.7 , and melting point and boiling point of $267-269^{\circ} \mathrm{C}$ and $570.0 \pm 50.0^{\circ} \mathrm{C}$, respectively. ${ }^{18-20} \mathrm{MA}$ possesses a wide range of pharmacological benefits, including anti-cancer, ${ }^{21}$ antiinflammatory and analgesic effects, ${ }^{22-24}$ antiplatelet aggregation, ${ }^{25,26}$ cardioprotective and antiinflammatory, ${ }^{27,28}$ antimicrobial, ${ }^{29,30}$ hepatoprotective, ${ }^{31}$ anti-diabetic, and anti-hyperlipidemic, ${ }^{32,33}$ to name a few. Among these effects, it has strong clinical potential. Recent studies have focused on anticancer activity of MA, emphasizing its promising properties as an anticancer agent and as a candidate for developing anticancer drugs. In this review, we searched all relevant research papers on MA as an effective anti-cancer treatment published by PubMed and Web of Sciences in the past ten years. The search strategy implemented was to use several keywords to track related research articles, including "pentacyclic triterpenes acid," "Maslinic acid," "cancer," tumour," "anti-cancer," and "cell death." We then analyzed and summarized all retrieved data. This review provides a basis for MA application in cancer prevention and treatment.

\section{Anticancer Properties of Maslinic Acid}

The therapeutic potential of MA for different cancers has been confirmed by a large number of preclinical experiments highlighting its role in regulating different cancer effects (ie, inhibiting proliferation, promoting apoptosis, regulating autophagy, and blocking angiogenesis). The cytotoxicity of MA to different cancer cells and corresponding IC50 values are briefly summarized below (Figure 2).

\section{Colorectal Cancer}

Colorectal cancer (CRC) has maintained high incidence rates in western countries. About 60,000 people in Germany are diagnosed with CRC every year and two-thirds of tumors are located in the colon. ${ }^{34-36}$ With alterations in people's lifestyle and dietary structure, the incidence of CRC is increasing among the young population. ${ }^{37}$ In the United States, morbidity and mortality rates among adults over the age of 50 have declined since the early 1990s, owing to advances in

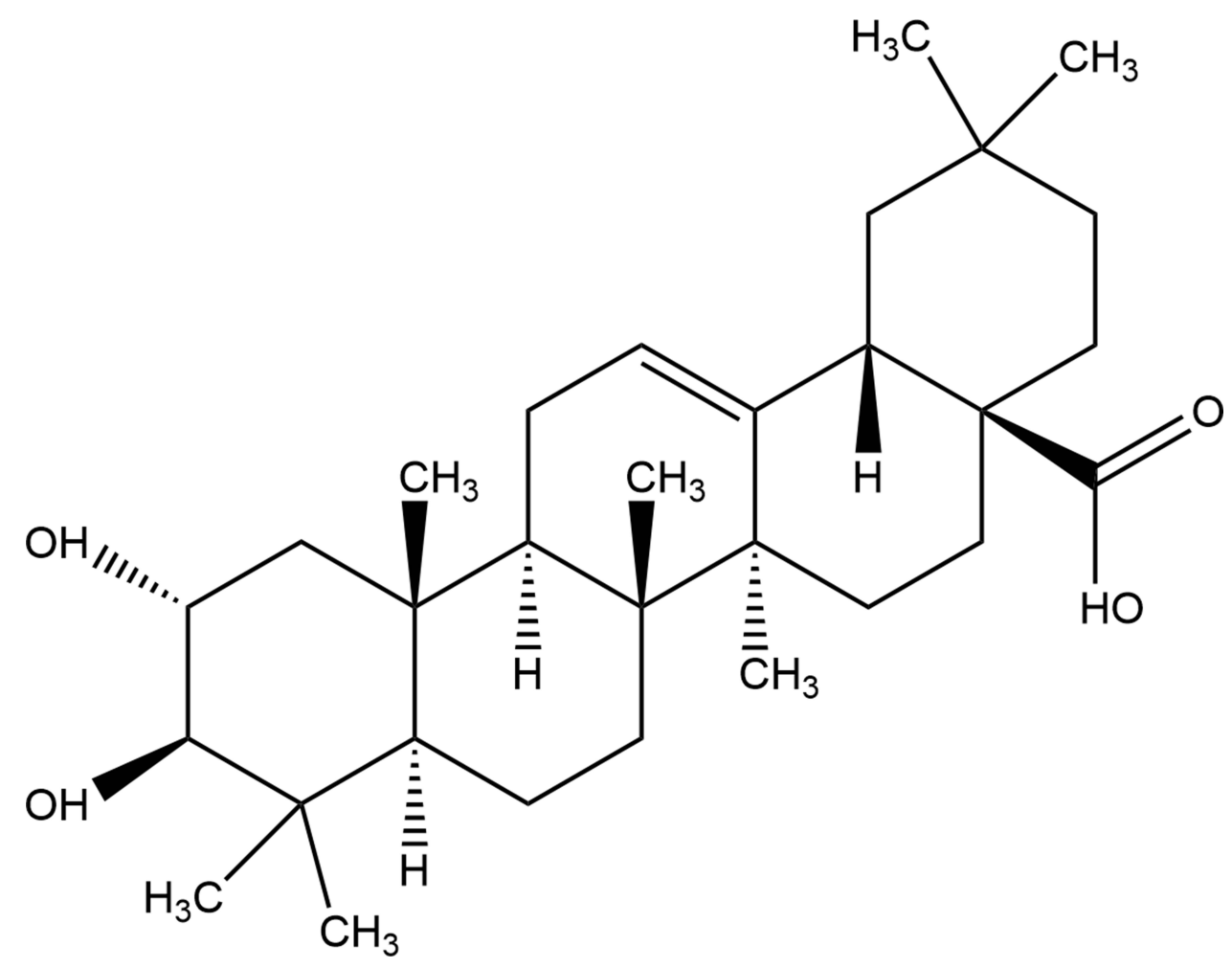

Figure I Chemical structure of MA. 


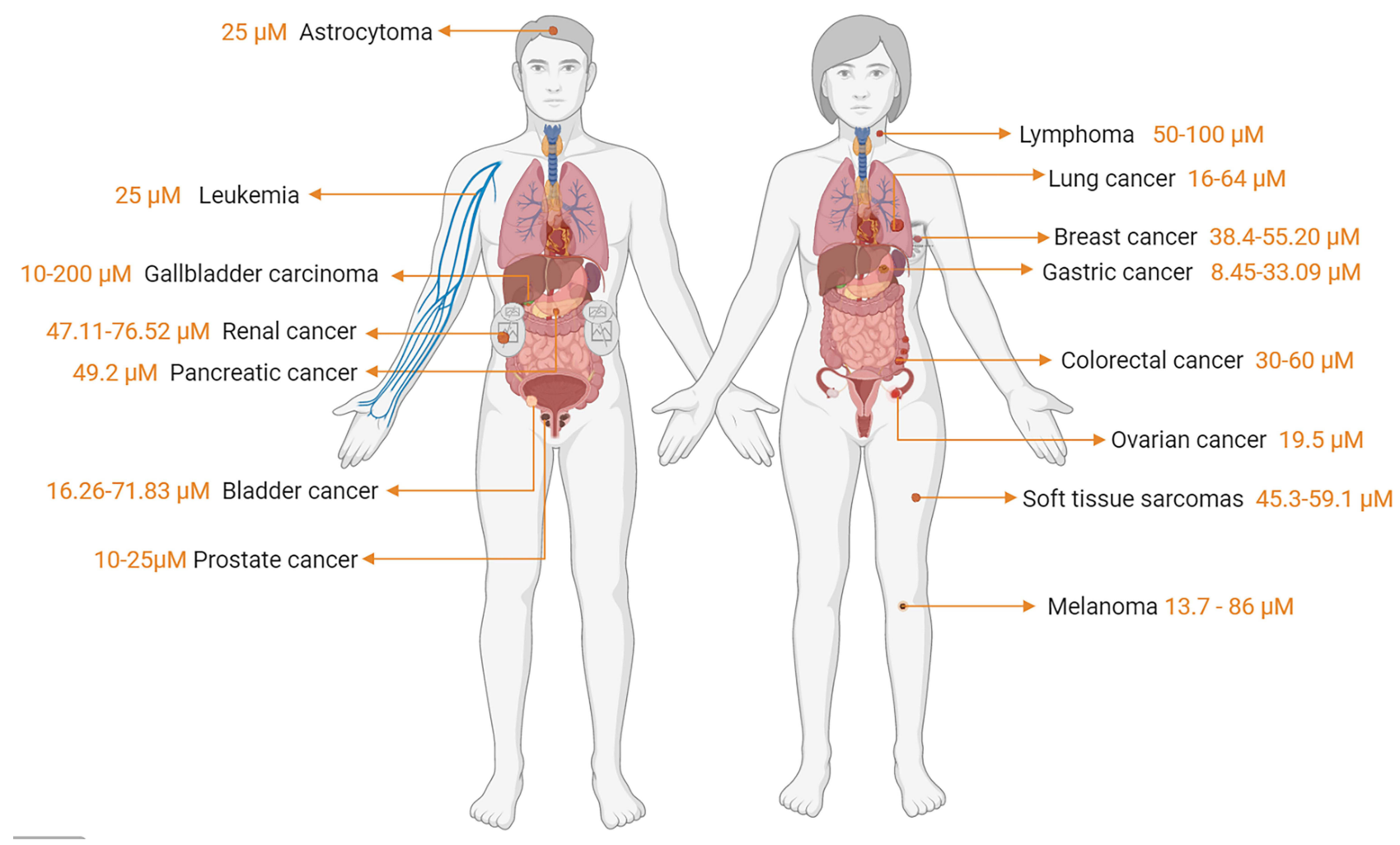

Figure 2 Anticancer properties of $M A$ and its corresponding $I C_{50}$ values. Note: Created with BioRender.com.

screening and treatment. However, CRC incidence in adults under the age of 50 continues to rise. ${ }^{38,39}$ Currently, most CRC deaths are caused by metastasis. In recent years, MA has shown excellent efficacy in treating CRC. In vivo, MA could reduce the content of preneoplastic biomarkers in 1,2-dimethylhydrazine -induced colon cancer rat models and $5 \mathrm{mg} / \mathrm{kg}$ MA could decrease aberrant crypt foci and mucin-depleted foci amount by $15 \%$ and $27 \%$, respectively; when MA was $25 \mathrm{mg} / \mathrm{kg}$, the amount decreased by $33 \%$ and $51 \%$, respectively (Table 1 ). ${ }^{40}$ Further, the $\mathrm{Apc}^{\mathrm{Min} /+}$ mouse model is widely used in the study of human chemotherapeutic agents because it can simulate human spontaneous intestinal tumorigenesis. A recent study showed that $\mathrm{Apc}^{\mathrm{Min} /+}$ mice treated with $100 \mathrm{mg} / \mathrm{kg}$ MA for six weeks reduced the formation of total intestinal polyps by $45 \%{ }^{41}$ In addition, the anti-colon cancer properties of MA have been demonstrated in vitro. Recent studies revealed that MA exerted anti-colon cancer effects by inhibiting cell proliferation and promoting cell apoptosis. ${ }^{42} \mathrm{MA}$ at $\mathrm{IC}_{50}$ of $39.7 \pm 0.4 \mu \mathrm{g} / \mathrm{mL}$ and $\mathrm{IC}_{80}$ of $56.8 \pm 0.1 \mu \mathrm{g} / \mathrm{mL}$ remarkably reduced Caco- 2 human colon cancer cell proliferation and increased apoptosis (Table 2). ${ }^{43}$ Another experiment exhibited similar results by illustrating $\mathrm{IC}_{50}$ and $\mathrm{IC}_{80}$ of MA in colon cancer cells were
$40.7 \pm 0.4 \mu \mathrm{g} / \mathrm{mL}$ and $56.8 \pm 0.1 \mu \mathrm{g} / \mathrm{mL}$, respectively. ${ }^{44}$ For HT29 cells, $\mathrm{IC}_{50}(28.8 \pm 0.9 \mu \mathrm{g} / \mathrm{mL})$ and $\mathrm{IC}_{80}(37.5 \pm 0.2 \mu \mathrm{g} /$ $\mathrm{mL}$ ) concentrations at 72 hours of MA could significantly induce cell apoptosis. ${ }^{45}$ Another study demonstrated that MA negatively affected HT29 cell proliferation at concentrations of $3.7 \mu \mathrm{M}\left(\mathrm{IC}_{50} / 8\right)$ and $30 \mu \mathrm{M}\left(\mathrm{IC}_{50}\right){ }^{46}$

\section{Melanoma}

Cutaneous melanoma is a serious malignant tumor, ranking third in skin malignant tumors and becoming the first fatal skin disease. The increased risk of skin melanoma is related to factors such as exposure to ultraviolet light and genetics. ${ }^{47,48}$ Mokhtari et al proved that MA can influence B16F10 melanoma cells grown under stressful conditions, where MA showed different $\mathrm{IC}_{50}$ values for $\mathrm{B} 16 \mathrm{~F} 10$ melanoma cells under different conditions. When 10\% FBS was added to the medium, its $\mathrm{IC}_{50}$ value was $36.88 \mu \mathrm{g} / \mathrm{mL}$ $(86 \mu \mathrm{M})$ and when the medium was $0 \% \mathrm{FBS}$, its $\mathrm{IC}_{50}$ value became $1.48 \mu \mathrm{g} / \mathrm{mL}(3.5 \mu \mathrm{M})$. It is possible that the lack of FBS reduces cell activity, which in turn reduces the $\mathrm{IC}_{50}$ value of MA. ${ }^{49}$ Moreover, Mokhtari et al demonstrated the inhibitory effect of MA on melanoma cells by adding $0.15 \mathrm{mM} \mathrm{H}_{2} \mathrm{O}_{2}$ to murine skin melanoma (B16F10) 
Table I The Anticancer Effects of MA in vivo

\begin{tabular}{|c|c|c|c|c|c|c|c|}
\hline $\begin{array}{l}\text { Cancer } \\
\text { Types }\end{array}$ & Animals & Models & $\begin{array}{l}\text { MA } \\
\text { Concentrations }\end{array}$ & $\begin{array}{l}\text { Route of } \\
\text { Administration }\end{array}$ & $\begin{array}{l}\text { Administration } \\
\text { Times }\end{array}$ & Effects & References \\
\hline \multirow[t]{3}{*}{$\begin{array}{l}\text { Colorectal } \\
\text { cancer }\end{array}$} & $\begin{array}{l}\text { 4-week- } \\
\text { old male } \\
\text { mice }\end{array}$ & $\begin{array}{l}\text { ApcMin/+ } \\
\text { intestinal polyp } \\
\text { mouse model }\end{array}$ & $\begin{array}{l}100 \mathrm{mg} M A / \mathrm{kg} \\
\text { feed }\end{array}$ & $\begin{array}{l}\text { Diet } \\
\text { supplemented }\end{array}$ & 6 weeks & $\begin{array}{l}\text { Reduced total } \\
\text { intestinal polyp } \\
\text { formation by } 45 \%\end{array}$ & [4I] \\
\hline & $\begin{array}{l}\text { 6-week- } \\
\text { old male } \\
\text { C57BL/6] } \\
\text { mice }\end{array}$ & $\begin{array}{l}\text { Azoxymethane } \\
\text { (AOM)/dextran } \\
\text { sulfate sodium } \\
\text { (DSS) mice } \\
\text { model }\end{array}$ & $\begin{array}{l}10 \mathrm{mg} / \mathrm{kg} \text { and } \\
30 \mathrm{mg} / \mathrm{kg} \text { day- } \mathrm{I}\end{array}$ & Orally & 40 days & $\begin{array}{l}\text { Protects against } \\
\text { DSS-induced acute } \\
\text { colitis, attenuated } \\
\text { the increase of } \\
\text { tumors. } \downarrow \text { IL-6, } \\
\downarrow \text { TNF- } \alpha, \uparrow \text { IL-I0, }\end{array}$ & [42] \\
\hline & $\begin{array}{l}\text { 5-week- } \\
\text { old male } \\
\text { BALB/c } \\
\text { nude } \\
\text { mice }\end{array}$ & $\begin{array}{l}\text { HCTII6 } \\
\text { xenograft } \\
\text { model }\end{array}$ & $\begin{array}{l}10 \mathrm{mg} / \mathrm{kg} \text { and } \\
30 \mathrm{mg} / \mathrm{kg} \text { day- } \mathrm{I}\end{array}$ & Orally & 17 days & $\begin{array}{l}\text { Suppressed the } \\
\text { tumorigenesis, } \\
\downarrow \mathrm{P}-\mathrm{mTOR}, \\
\downarrow \mathrm{P}-4 \mathrm{EBPI}, \\
\downarrow \mathrm{P} 70 \mathrm{S6K}, \uparrow \mathrm{P}-\mathrm{AMPK} .\end{array}$ & [42] \\
\hline Leukemia & $\begin{array}{l}\text { 5-week- } \\
\text { old male } \\
\text { BALB/c } \\
\text { mice }\end{array}$ & $\begin{array}{l}\text { WEHI-3 } \\
\text { xenograft } \\
\text { model }\end{array}$ & $0,8,16,32 \mathrm{mg} / \mathrm{Kg}$ & $\begin{array}{l}\text { Intraperitoneal } \\
\text { injection }\end{array}$ & 2 weeks & $\begin{array}{l}\text { Increase immune } \\
\text { responses: } \\
\text { enhanced } \\
\text { macrophage } \\
\text { phagocytosis and } \\
\text { NK cell activities }\end{array}$ & [80] \\
\hline $\begin{array}{l}\text { Pancreatic } \\
\text { cancer } \\
\text { er }\end{array}$ & $\begin{array}{l}4-5 \\
\text { week-old } \\
\text { athymic } \\
\text { nu/nu } \\
\text { male } \\
\text { mice }\end{array}$ & $\begin{array}{l}\text { Panc-28 } \\
\text { xenograft } \\
\text { model }\end{array}$ & $\begin{array}{l}10,50 \mathrm{mg} / \mathrm{kg} \text { MA } \\
\text { every } 2 \text { day }\end{array}$ & $\begin{array}{l}\text { Subcutaneous } \\
\text { injected }\end{array}$ & 36 days & $\begin{array}{l}\text { Suppressed } \\
\text { pancreatic tumor } \\
\text { growth, induced } \\
\text { tumor apoptosis, } \\
\text { and inhibited NF- } \\
\text { B-regulated anti- } \\
\text { apoptotic gene } \\
\text { expression, such as } \\
\text { Survivin and Bcl-xl. }\end{array}$ & [112] \\
\hline $\begin{array}{l}\text { Gallbladder } \\
\text { cancer }\end{array}$ & $\begin{array}{l}\text { 6-week- } \\
\text { old } \\
\text { athymic } \\
\text { nu/nu } \\
\text { male } \\
\text { mice }\end{array}$ & $\begin{array}{l}\text { EH-GB2 } \\
\text { xenograft } \\
\text { model }\end{array}$ & $\begin{array}{l}30 \mathrm{mg} / \mathrm{kg} \text { MA } \\
\text { every } 2 \text { days } \\
+\mathrm{GEM}\end{array}$ & $\begin{array}{l}\text { Subcutaneously } \\
\text { injected }\end{array}$ & 30 days & $\begin{array}{l}\text { Inhibitory tumor } \\
\text { volume, and } \\
\text { decreased NF- } \\
\text { ๔B-regulated gene } \\
\text { products } \\
\text { expression. }\end{array}$ & [90] \\
\hline
\end{tabular}

cells and healthy cells (A10) to stress the cells and explore the role of MA in protecting cell lines from oxidative damage under stress conditions. The results showed that MA could reestablish superoxide dismutase, glutathione S-transferase, and glutathione peroxidase activity caused by $\mathrm{H} 2 \mathrm{O} 2$ in $\mathrm{B} 16 \mathrm{~F} 10$ cells compared to A10. MA showed significant cytotoxicity in $\mathrm{B} 16 \mathrm{~F} 10$ cells with an $\mathrm{IC}_{50}$ value of $42 \mu \mathrm{M}$, but no obvious toxicity for A10 cells at concentrations up to $210 \mu \mathrm{M}^{50}$

\section{Lymphoma}

Lymphoid malignancies differ from other malignant tumors and are widely regarded as neoplastic and inflammatory diseases. They are part of the immune system and consist of inflammation/immune cell microenvironments. ${ }^{51}$ Hsum et al demonstrated that MA inhibits proliferation of Raji cells by inhibiting Cox-2 expression with an $\mathrm{IC}_{50}$ value of $100 \mu \mathrm{M}^{52}$ Similarly, Hsum et al revealed that MA suppressed cell proliferation of Raji cells in a dose- and 
Table 2 The Anticancer Effects of MA in vitro

\begin{tabular}{|c|c|c|c|c|c|c|}
\hline Cancer Types & $\begin{array}{l}\text { Cell } \\
\text { Lines }\end{array}$ & MA Concentration & $1 C_{50}$ & $\begin{array}{l}\text { Exposure } \\
\text { Time }\end{array}$ & Effects & References \\
\hline \multirow[t]{5}{*}{ Colorectal cancer } & $\begin{array}{l}\text { Caco-2 } \\
\text { colon } \\
\text { cancer } \\
\text { cells }\end{array}$ & $0-100 \mu g / m L$ & $\begin{array}{l}39.7 \\
\pm 0.4 \mu \mathrm{g} / \mathrm{mL}\end{array}$ & $72 \mathrm{~h}$ & $\begin{array}{l}\uparrow \text { caspase-8 /caspase-3, } \uparrow \text { caspase-9, } \\
\uparrow \text { JNK, } \downarrow \text { Bid, } \downarrow \text { Bcl-2 }\end{array}$ & [43] \\
\hline & $\begin{array}{l}\text { HCTII6, } \\
\text { SW480 } \\
\text { cells }\end{array}$ & $5,10,20,30 \mu \mathrm{M}$ & 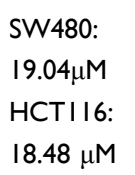 & $12 \mathrm{~h}$ & $\begin{array}{l}\uparrow \text { cleaved caspase-3, }-9, \downarrow \mathrm{Bcl}-2 ; \uparrow \mathrm{P}- \\
\text { AMPK, } \uparrow(\mathrm{AMP}+\mathrm{ADP}) / \mathrm{ATP} ; \downarrow \mathrm{P}-\mathrm{mTOR}, \\
\downarrow \mathrm{P}-4 \mathrm{EBPI} \text { and } \mathrm{p} 70 \mathrm{~S} 6 \mathrm{~K}\end{array}$ & [42] \\
\hline & $\begin{array}{l}\text { Caco-2 } \\
\text { colon } \\
\text { cancer } \\
\text { cells }\end{array}$ & $\begin{array}{l}\mathrm{IC}_{50}: 40.7 \mu \mathrm{g} / \mathrm{mL} \\
\mathrm{IC}_{80}: 56.8 \mu \mathrm{g} / \mathrm{mL}\end{array}$ & $40.7 \mu \mathrm{g} / \mathrm{mL}$ & $72 \mathrm{~h}$ & $\begin{array}{l}\uparrow \text { cleavage of caspases }-8 \text { and }-3, \uparrow \mathrm{t}-\mathrm{Bid} \text {, } \\
\uparrow \text { cytochrome } \mathrm{C} \text { release }\end{array}$ & [44] \\
\hline & $\begin{array}{l}\text { HT29 } \\
\text { cells }\end{array}$ & $0-100 \mu \mathrm{g} / \mathrm{mL}$ & $\begin{array}{l}39.7 \\
\pm 0.4 \mu \mathrm{g} / \\
\mathrm{mL}\end{array}$ & $72 \mathrm{~h}:$ & $\begin{array}{l}\downarrow \mathrm{Bcl}-2, \uparrow \mathrm{Bax}, \uparrow \text { cytochrome C, } \\
\uparrow \text { Caspase- } 9 \text { and Caspase-3 }\end{array}$ & [45] \\
\hline & $\begin{array}{l}\text { HT29 } \\
\text { cells }\end{array}$ & $\begin{array}{l}3.75,7.5,15 \text { and } 30 \\
\mu \mathrm{M}\end{array}$ & $30 \mu \mathrm{M}$ & $\begin{array}{l}3,12,24 \\
48,72 \mathrm{~h}\end{array}$ & - & [46] \\
\hline \multirow[t]{2}{*}{ Melanoma } & $\begin{array}{l}\text { BI6FI0 } \\
\text { cells }\end{array}$ & $10-100 \mu \mathrm{g} / \mathrm{mL}$ & - & $24 \mathrm{~h}$ & $\uparrow R O S$ & [49] \\
\hline & $\begin{array}{l}\text { BI6FIO } \\
\text { and AIO } \\
\text { cells }\end{array}$ & $\begin{array}{l}I C_{50} / 4, I C_{50} / 2, I C_{50} \\
2 \cdot I C_{50}\end{array}$ & $42.3 \mu \mathrm{M}$ & - & $\downarrow$ SOD, $\downarrow$ GSTs, $\downarrow$ GSH-Px. & [50] \\
\hline \multirow[t]{3}{*}{ Lymphoma } & Raji cells & $12.5,25,50,100 \mu \mathrm{M}$ & $100 \mu \mathrm{M}$ & $8 \mathrm{~h}$ & $\downarrow C O X-2, \downarrow N F-\kappa B, \downarrow A P-\mid$ & [52] \\
\hline & Raji cells & $I C_{50}: 0.1 \mu \mathrm{m} / \mathrm{mL}$ & $100 \mu \mathrm{M}$ & $72 \mathrm{~h}$ & - & [54] \\
\hline & Raji cells & $\begin{array}{l}12.5,25,50,100 \text { and } \\
200 \mu \mathrm{M}\end{array}$ & - & $\begin{array}{l}4,8,16,24 \\
48, \text { and } 72 \\
h\end{array}$ & $\begin{array}{l}\downarrow \text { dUTPase, } \downarrow \text { stathmin, } \downarrow \text { cyclin DI, } \uparrow p 2 I \\
\text { protein, } \downarrow \text { NF- } k B\end{array}$ & [53] \\
\hline \multirow[t]{2}{*}{ Lung cancer } & $\begin{array}{l}\text { A549 } \\
\text { cells }\end{array}$ & $\begin{array}{l}0,9,12,15,18,21 \mu g / \\
\mathrm{mL}\end{array}$ & - & $24 \mathrm{~h}$ & $\begin{array}{l}\downarrow \text { caspase- } 3,-8 \text { and }-9, \uparrow \text { cleaved } \\
\text { caspase-3, }-8 \text { and }-9 . \\
\uparrow \text { Smac, } \downarrow \text { c-IAPI, c-IAP2, X-linked } \\
\text { inhibitor of apoptosis protein, } \\
\downarrow(\text { XIAP }) \text { and Survivin }\end{array}$ & [58] \\
\hline & $\begin{array}{l}\text { A549 } \\
\text { cells }\end{array}$ & $0,4,8,16,32,64 \mu \mathrm{M}$ & - & - & $\begin{array}{l}\downarrow \mathrm{Bcl}-2, \downarrow \mathrm{Na}+-\mathrm{K}+-\mathrm{ATPase} \text { activity, } \\
\uparrow \text { caspase-3/8, } \uparrow \text { cytochrome c, } \downarrow \text { HIF- } \mid \alpha, \\
\downarrow \text { VEGF, } \downarrow \text { survivin, } \downarrow \text { iNOS }\end{array}$ & [59] \\
\hline \multirow[t]{2}{*}{$\begin{array}{l}\text { Triple negative } \\
\text { breast carcinoma }\end{array}$} & $\begin{array}{l}\text { MDA-MB } \\
-23 \text { I, } \\
\text { MDA-MB } \\
-468, \\
\text { MCF7 } \\
\text { cells }\end{array}$ & $30-50 \mu \mathrm{M}$ & - & $24 \mathrm{~h}$ & $\begin{array}{l}\downarrow \mathrm{CDK} 4, \downarrow \mathrm{CDK} 2 \text { (TNBCs) } \uparrow \mathrm{CDK} 2 \\
\text { (MCF7); } \uparrow \mathrm{Bax}, \downarrow \mathrm{BCL} 2, \uparrow \mathrm{Bax} / \mathrm{Bcl}-2 \\
\text { ratio. } \downarrow \text { survivin }\end{array}$ & [64] \\
\hline & $\begin{array}{l}\text { MDA-MB } \\
-23 \text { I cells }\end{array}$ & $0-20 \mu \mathrm{M}$ & - & $24 \mathrm{~h}$ & $\begin{array}{l}\text { MA+DOC: } \downarrow \text { MELK, } \downarrow \text { FoxMI, } \downarrow \text { FoxMI, } \\
\downarrow \text { ABCB }\end{array}$ & [65] \\
\hline
\end{tabular}


Table 2 (Continued).

\begin{tabular}{|c|c|c|c|c|c|c|}
\hline Cancer Types & $\begin{array}{l}\text { Cell } \\
\text { Lines }\end{array}$ & MA Concentration & $I C_{50}$ & $\begin{array}{l}\text { Exposure } \\
\text { Time }\end{array}$ & Effects & References \\
\hline Ovarian cancer & $\begin{array}{l}\text { A2780 } \\
\text { cells }\end{array}$ & I, $24,60 \mu \mathrm{M}$ & - & $6,12,24 \mathrm{~h}$ & - & {$[104]$} \\
\hline \multirow[t]{2}{*}{ Gastric Cancer } & $\begin{array}{l}\text { SGC-790 } \\
\text { cells }\end{array}$ & $0-50 \mu \mathrm{M}$ & $\begin{array}{l}33.09 \\
\pm 3.15\end{array}$ & $6,24 h$ & $\uparrow p 38$ MAPK, $\uparrow$ caspase & [69] \\
\hline & $\begin{array}{l}\text { MKN28 } \\
\text { cells }\end{array}$ & $0,0.1, I, 10 \mu \mathrm{M}$ & $8.45 \mu \mathrm{M}$ & $24 \mathrm{~h}$ & $\begin{array}{l}\downarrow \text { Bcl2, Bax and Bad; } \downarrow \text { IL-6/JAK/STAT3 } \\
\text { signaling cascade: }(\downarrow \text { p-STAT3 and JAK2, } \\
\downarrow \text { IL-6 }\end{array}$ & [70] \\
\hline \multirow[t]{2}{*}{$\begin{array}{l}\text { Pancreatic cancer } \\
\text { er }\end{array}$} & $\begin{array}{l}\text { Panc-28 } \\
\text { cells }\end{array}$ & $\begin{array}{l}6.25,12.5,25,50 \\
100, \text { and } 200 \mu \mathrm{M}\end{array}$ & $\begin{array}{l}49.2 \pm 0.5 \\
\mu \mathrm{M}\end{array}$ & $48 \mathrm{~h}$ & $\begin{array}{l}\uparrow L C 3-I I / L C 3-I, \uparrow A \operatorname{tg} 7, \text { Atgl6L, Atg5, } \\
\text { AtgI } 2 \text { and Atg3, } \downarrow \text {-mTOR, } \uparrow \text {-ULKI } \\
\text { (via } \uparrow H S P A 8 \text { ) }\end{array}$ & [73] \\
\hline & $\begin{array}{l}\text { Panc-28 } \\
\text { cells }\end{array}$ & $10 \mu \mathrm{M}$ & - & $\begin{array}{l}6,12,24, \\
48 \mathrm{~h}\end{array}$ & $\begin{array}{l}\text { MA+TNF } \alpha \\
\uparrow p 65 ; \downarrow c e l l \text { proliferation gene (Cyclin } \\
\text { DI, CO-2 and c-Myc), } \downarrow \text { apoptosis } \\
\text { (Survivin), Bcl-2, Bcl-xl, XIAP, IAP-I), } \downarrow \\
\text { invasion (MMP-9 and ICAM-I), } \downarrow \\
\text { angiogenesis (VEGF) }\end{array}$ & [112] \\
\hline Bladder cancer & $\begin{array}{l}\text { T24, 253J, } \\
\text { MRC-5 } \\
\text { cells }\end{array}$ & $0-100 \mu \mathrm{M}$ & $\begin{array}{l}\text { T24:32.98 } \\
\pm 4.06 \mu \mathrm{M} \\
253 \mathrm{~J}: 7 \mathrm{II} .83 \\
\pm 5.42 \mu \mathrm{M} \\
\mathrm{MRC}- \\
5: 328.75 \pm \\
40.64 \mu \mathrm{M}\end{array}$ & $48 \mathrm{~h}$ & $\uparrow$ P38 MAPK & [77]] \\
\hline Prostate canc & $\begin{array}{l}\text { DUI45 } \\
\text { cells }\end{array}$ & $0-25 \mu \mathrm{M}$ & - & $24 \mathrm{~h}$ & $\begin{array}{l}\downarrow \text { uPAR, E-cadherin, VEGF and MMP; } \downarrow \\
\text { HIF- Ia, } \downarrow \text { Akt and ERK }\end{array}$ & [84] \\
\hline Renal cancer & $\begin{array}{l}\text { RCC, } \\
\text { SNI } 2 K I, \\
\text { HUVEC, } \\
\text { PTEC } \\
\text { cells }\end{array}$ & $0-100 \mu \mathrm{M}$ & - & $24 \mathrm{~h}$ & $\downarrow$ VEGF & [87] \\
\hline $\begin{array}{l}\text { Gallbladder } \\
\text { carcinoma }\end{array}$ & $\begin{array}{l}-\mathrm{EH}-\mathrm{GBI} \text {, } \\
\text { EH-GB2 } \\
\text { and GBC- } \\
\text { SD cells }\end{array}$ & $10-200 \mu \mathrm{M}$ & - & $\begin{array}{l}0,12,24, \\
48 \mathrm{~h}\end{array}$ & $\begin{array}{l}\text { MA+ GEM } \\
\downarrow N F-\kappa B, \downarrow \text { cyclin DI, Bcl-2, Bax, MMP-2 } \\
\text { and MMP-9. } \\
\text {. }\end{array}$ & [90] \\
\hline Astrocytoma & $\begin{array}{l}\text { I32INI } \\
\text { cells }\end{array}$ & $\mathrm{I}-50 \mu \mathrm{M}$ & $25 \mu \mathrm{M}$ & $24 \mathrm{~h}$ & $\begin{array}{l}\uparrow \text { caspase- } 3, \\
\uparrow \text { ROS }\end{array}$ & [93] \\
\hline $\begin{array}{l}\text { Adenoid cystic } \\
\text { carcinoma }\end{array}$ & $\begin{array}{l}\text { ACC-2 } \\
\text { and } \\
\text { ACC-M } \\
\text { cells }\end{array}$ & $0-100 \mu \mathrm{M}$ & $\begin{array}{l}\text { ACC-2: } \\
43.68 \mu \mathrm{M}, \\
\text { ACC-M: } \\
45.76 \mu \mathrm{M}\end{array}$ & $\begin{array}{l}24 \mathrm{~h}, 48 \mathrm{~h}, \\
72 \mathrm{~h}\end{array}$ & $\begin{array}{l}\uparrow[\mathrm{Ca} 2+]^{\mathrm{i}}, \uparrow p 38 \mathrm{MAPK} \text { phosphorylation, } \\
\uparrow \text { caspase- } 3\end{array}$ & {$[117]$} \\
\hline Pheochromocytoma & $\begin{array}{l}\mathrm{PCI} 2 \\
\text { cells }\end{array}$ & $\mathrm{I}, 3,5,10 \mu \mathrm{M}$ & - & $24 \mathrm{~h}$ & $\uparrow$ LC3-I/II conversion, $\downarrow$ Beclin I & [96] \\
\hline
\end{tabular}


Table 2 (Continued).

\begin{tabular}{|l|l|l|l|l|l|l|}
\hline Cancer Types & $\begin{array}{l}\text { Cell } \\
\text { Lines }\end{array}$ & MA Concentration & $\mathbf{I} \mathbf{C}_{\mathbf{5 0}}$ & $\begin{array}{l}\text { Exposure } \\
\text { Time }\end{array}$ & Effects & References \\
\hline Neuroblastoma & $\begin{array}{l}\text { SHSY-5Y } \\
\text { cells }\end{array}$ & $0,5,10,20,40,80 \mu \mathrm{M}$ & - & $12 \mathrm{~h}, 48 \mathrm{~h}$ & $\uparrow$ ROS, $\downarrow$ MAPK/ERK & [97] \\
\hline Soft tissue sarcomas & $\begin{array}{l}\text { SW982 } \\
\text { and SK- } \\
\text { UT-I cells }\end{array}$ & $10-100 \mu \mathrm{M}$ & - & $24 \mathrm{~h}$ & MA+DXR: $\downarrow$ MRP-I & {$[98]$} \\
\hline
\end{tabular}

time-dependent manner, where the proliferation inhibition rates of MA $(50 \mu \mathrm{M})$ at $24 \mathrm{~h}, 48 \mathrm{~h}$, and $72 \mathrm{~h}$ were $46 \%$, $76 \%$, and $97 \%$, respectively. ${ }^{53}$ Furthermore, another study also showed that MA inhibited Epstein-Barr virus (EBV) early-antigen expression in Raji cells with an $\mathrm{IC}_{50}$ value of $0.1 \pm 0.04 \mu \mathrm{g} / \mathrm{mL}$. Phorbol 12-myristate 13-acetate (PMA) can also induce early-antigen EBV expression; the antitumor activity of MA may be attributed to its hydrophilic moieties interacting with protein kinase $\mathrm{C}$, which prevents PMA from binding and activating protein kinase C. ${ }^{54}$

\section{Lung Cancer}

Lung cancer is a crucial public disease with the highest mortality rate. According to reports, the 5-year survival rate of lung cancer patients has increased in the past 10 years. ${ }^{55-57}$ Consequently, lung cancer caused a heavy burden on public health. Bai et al found that MA in the concentration range of $9-21 \mu \mathrm{g} / \mathrm{mL}$ significantly suppressed cell proliferation and accelerated apoptosis of A549 lung cancer cells in a dose-dependent manner after $24 \mathrm{~h}$ treatment. ${ }^{58}$ Likewise, Hsia et al reported MA exhibited a significant pro-apoptotic effect when targeting A549 cells under normoxic and hypoxic conditions at concentration ranges of 4-64 $\mu \mathrm{M}$ and $16-64 \mu \mathrm{M}$, respectively. Notably, the stronger pro-apoptotic effect of MA on A549 cells was observed under normoxic than hypoxic conditions at the same dose. ${ }^{59}$

\section{Breast Cancer}

To date, breast cancer remains the second leading cause of cancer-related deaths among women worldwide. Finding molecular markers and targeted therapies for specific subgroups of breast cancer patients is currently an urgent task. $^{60,61}$ Triple negative breast cancer (TNBC) is an aggressive subtype of breast cancer that accounts for approximately $15-20 \%$ of all breast carcinomas. Compared with hormone receptor- or HER2-positive breast carcinoma, TNBC has an earlier onset age, a more invasive clinical course, and a bleak prognosis, which mainly relies on cytotoxic chemotherapy. However, due to the lack of expression of three effective breast cancer molecular markers, such as estrogen and progesterone receptors, as well as HER-2/Neu amplification, TNBC chemotherapy is not sufficiently effective. ${ }^{62,63} \mathrm{~A}$ recent study confirmed the anti-tumor effect of MA on TNBC by suppressing cell proliferation for both estrogen positive MCF7 and TNBC cells (namely, MDA-MB-231 and MDA-MB-468). In MDA-MB-231 cells, the $\mathrm{IC}_{50}$ value of MA at $24 \mathrm{~h}$ was $38.34 \mu \mathrm{M}$; in MDA-MB-468, the $\mathrm{IC}_{50}$ value of MA was $49.57 \mu \mathrm{M}$; in MCF7 cell lines, the $\mathrm{IC}_{50}$ value of MA was $55.20 \mu \mathrm{M}$. MA also initiated apoptosis and cell death, which was positively associated with the adhesive and migratory capabilities of cancer cells. ${ }^{64}$ Docetaxel is a commonly used chemotherapy agent for treating TNBC. However, drug resistance caused by longterm use reduces its therapeutic effects. Wang $\mathrm{K}$ et al proved that docetaxel combined with different doses of MA $(2.5,5$, and $10 \mu \mathrm{M})$ could significantly improve the sensitivity of MDA-MB-231 cells to docetaxel and reduce drug resistance in a dose-dependent manner, which supports MA as a promising contributor of docetaxel resistance in human TNBC therapy. ${ }^{65}$

\section{Gastric Cancer}

Gastric cancer (GC) is a leading global cause of cancer mortality. Due to the inapparent clinical symptoms during early stages, many GC patients miss the optimal treatment period. In addition to radical gastrectomy, fluorouracilbased adjuvant chemotherapy is the first-line adjuvant therapy for patients with advanced GC. Cardia cancer is the most common subtype of GC, with increasing incidence rate and poor prognosis, whose 5-year survival rate is reportedly only $16.7 \% .^{66-68}$ Chang $\mathrm{T}$ et al established a tumor model by subcutaneously injecting SGC-7901 into 
nude mice to investigate the preventative properties of MA against GC. They found that MA significantly inhibited tumor growth in a dose-dependent manner and $20 \mathrm{mg} / \mathrm{kg}$ MA could suppress growth of xenograft tumors by approximately $50 \%$. Further, the latter study revealed $\mathrm{IC}_{50}$ values of MA on SGC-7901 and BGC-823 cells were $33.09 \mu \mathrm{M}$ and $23.85 \mu \mathrm{M}$, respectively. ${ }^{69}$ Furthermore, another study manifested that MA supplements significantly inhibited proliferation of MKN28 GC cells and induced apoptosis in a dose-dependent manner, with an $\mathrm{IC}_{50}$ value of $8.45 \mu \mathrm{M} .^{70}$

\section{Pancreatic Cancer}

Pancreatic cancer ranks as the fourth leading cause of cancer death in the USA, with surgical resection being the only cure method as pancreatic cancer responds poorly to most chemotherapeutic agents. However, this cancer typically acts as a hidden disease evading early diagnosis and most patients lose the chance of surgical excision. Hence, finding new strategies for comprehensive treatment of pancreatic cancer is urgent. $^{71,72}$ MA can inhibit human pancreatic cancer Panc-28 cells with an $\mathrm{IC}_{50}$ value of $49.2 \pm 0.5 \mu \mathrm{M}$. MA also significantly induced autophagy at a concentration of $50 \mu \mathrm{M}$. $^{73}$

Tumor necrosis factor-alpha (TNF- $\alpha$ ) is a key proinflammatory factor. Generally, endogenous TNF- $\alpha$ physiologically secreted in the epithelial-to-mesenchymal transition of cancer patients promotes tumor growth and spread. Recently, TNF- $\alpha$ showed anti-tumor activity in several preclinical models and in non-comparative clinical trials. ${ }^{74}$ However, TNF- $\alpha$ is not established as an effective anti-cancer agent due to its systemic cytotoxicity and resistance to tumor cells. A recent study showed that MA inhibited TNF- $\alpha$ in pancreatic cancer cell proliferation in a dose-dependent manner at significant concentrations of $1.5 \mu \mathrm{M}$. Notably, the lethality of pancreatic cancer is due to its high invasiveness and tendency to metastasize rapidly in the lymphatic system. Pretreatment with $25 \mu \mathrm{M}$ MA for $12 \mathrm{~h}$ can inhibit pancreatic cancer cell invasion. Further, MA promoted TNF- $\alpha$-induced cell apoptosis. Moreover, treatment with two different doses $(10 \mathrm{mg} / \mathrm{kg}$ or $50 \mathrm{mg} / \mathrm{kg}$ ) of MA can suppress tumor growth induced by Panc-28 pancreatic cancer cells in mice. Compared with the control group, MA treatment reduced tumor volume and weight of mice in a dose-dependent manner. $^{75}$

\section{Bladder Cancer}

Bladder cancer is one of the ten most common malignant tumors and has the highest incidence among malignant tumors of the urinary system, which seriously threatens people's lives and health. Therefore, finding new molecular targeted drugs for treating bladder cancer is clinically pertinent. ${ }^{76}$ A recent study demonstrated that MA selectively inhibited growth of bladder cancer cells. In different bladder cancer cells, the $\mathrm{IC}_{50}$ values were as follows: $\mathrm{T} 24$ $(32.98 \pm 4.06 \mu \mathrm{M})$, TCCSUP $(27.95 \pm 3.72 \mu \mathrm{M}), 253 \mathrm{~J}$ $(71.83 \pm 5.42 \mu \mathrm{M})$, PBC-1 $(44.05 \pm 3.83 \mu \mathrm{M})$, and PBC-2 $(16.26 \pm 1.79 \mu \mathrm{M})$. Meanwhile, MA shows no obvious cytotoxicity to human lung fibroblasts (MRC-5) and normal liver cells (L-O2), with $\mathrm{IC}_{50}$ values of $328.75 \pm 40.64$ $\mu \mathrm{M}$ and $196.95 \pm 25.60 \mu \mathrm{M}$, respectively. In addition, different doses ( 5 and $20 \mathrm{mg} / \mathrm{kg}$ ) of MA significantly inhibited tumor growth in a BALB/C nude bladder cancer model induced by T24 and 253J cells, suggesting MA has significant therapeutic effects on bladder cancer. ${ }^{77}$

\section{Leukemia}

Leukemia is a malignant tumor of the hematopoietic system characterized by uncontrolled proliferation of immature blood cells, which has become a huge challenge due to high mortality and morbidity. ${ }^{78}$ Recently, MA of $25 \mu \mathrm{M}$ concentration inhibited proliferation of HL-60 cells without obvious inhibitory effects on proliferation of normal skin fibroblasts (NHSF46 and NB1RGB). ${ }^{79}$ Further, Lai et al confirmed the anti-leukemia effect of MA in mice leukemia models established by injecting WEHI-3 cells into the abdominal cavity of normal BALB/c mice. Following intraperitoneal injection with MA at different concentrations $(0,8,16$, and $32 \mathrm{mg} / \mathrm{kg})$ for two weeks, body weight of leukemia mice became slightly upregulated with no observed toxic reactions during treatment. In addition, the survival rate of leukemia mice improved with high MA doses $(32 \mathrm{mg} / \mathrm{kg}){ }^{80}$

\section{Prostate Cancer}

Prostate cancer is a common urogenital malignancy in aging men, accounting for approximately $15 \%$ of male cancer patients worldwide. Prostate cancer is almost always an adenocarcinoma that originates in glandular epithelial tissue, without obvious symptoms in its early stage. In its middle stage, it often manifests lower urinary obstruction symptoms, such as urinary frequency, urgency, and urinary incontinence. ${ }^{81,82}$ Epidermal growth factor 
(EGF) has previously been shown to stimulate migration, invasion, and adhesion of DU145 cells. ${ }^{83}$ A recent study suggested that MA could inhibit metastatic capacity of prostate cancer. First, cell proliferation experiments showed cell viability did not change after treatment with 10-25 $\mu \mathrm{M}$ of MA for $18 \mathrm{~h}$. Differing doses (10 and 25 $\mu \mathrm{mol} / \mathrm{l})$ of MA were then applied to prostate cancer cells, showing MA can inhibit basal and EGF-induced migration (27-64\%), invasion (23-60\%), and adhesion (8-40\%) of DU145 cells. ${ }^{84}$

\section{Renal Cancer}

Renal cell carcinoma (RCC) is diagnosed in approximately 300,000 people worldwide annually and causes more than 100,000 deaths. RCC is not a single disease, as it possesses many histological characteristics and clinical manifestations caused by different genes. Currently, the complexity and increasing incidence of kidney cancer, as well as the poor efficacy and high drug resistance of existing treatments, have increased the need for targeted therapies and precision medicine for kidney cancer. ${ }^{85,86}$ A recent study showed that dietary MA supplementation could reduce kidney cancer risk, as well as present an auxiliary method to improve efficacy of existing antiangiogenesis treatment. Treatment with MA for three RCC cell lines (Caki-1, SN12K1, and ACHN) showed $\mathrm{SN} 12 \mathrm{~K} 1$ was the most sensitive cell, with an $\mathrm{IC}_{50}$ value of $47.11 \mu \mathrm{M}$, while ACHN was the most tolerant cell, with an $\mathrm{IC}_{50}$ value of $76.52 \mu \mathrm{M}$. Further, under similar experimental conditions, MA was more toxic to RCC cell lines than kidney proximal tubular epithelial cells (PTEC), highlighting the selective toxicity of MA to RCC cells. Further studies showed that MA can inhibit proliferation, reduce proliferating cell nuclear antigen and suppress colony formation on RCC cells. ${ }^{87}$

\section{Gallbladder Carcinoma}

Gallbladder cancer is a malignant tumor originating from mucosal epithelial cells of the gallbladder. It is the most common malignant tumor in the biliary system, accounting for more than $70 \%$ of biliary malignancies. ${ }^{88,89}$ Gemcitabine (GEM) is a chemotherapeutic agent for treating advanced metastatic cholangiocarcinoma and gallbladder cancer. However, GEM resistance is seen in many types of cancer. Recently, an experiment treated GBC cell lines with five MA doses $(10,25,50,100$, and 200 $\mu \mathrm{M}$ ) and GEM (25 $\mathrm{nM}$ ) for $48 \mathrm{~h}$, revealing MA applied alone may significantly inhibit proliferation of GBC cells in a dose-dependent manner, but also combining MA and GEM may synergistically inhibit cell proliferation in GBC cells by strengthening apoptosis and inhibiting cell invasion. $^{90}$

\section{Other Cancers}

Astrocytoma is a glioma with good prognosis, is an invasive growth tumor, and can occur at any age. ${ }^{91,92}$ Recently, MA showed an anti-astrocytoma effect by inhibiting cell proliferation and inducing apoptosis. Specifically, Martín et al treated $1321 \mathrm{~N} 1$ cells with $1-50 \mu \mathrm{M} / \mathrm{L}$ MA, demonstrating an $\mathrm{IC}_{50}$ value of MA after $24 \mathrm{~h}$ was approximately $25 \mu \mathrm{M} /$ L. $^{93}$

Phaeochromocytomas are rare neuroendocrine tumors with a highly variable clinical presentation and common manifestations of headaches, sweating, palpitations, and hypertension. Closely related tumors, called extra-adrenal paragangliomas, can arise in extra-adrenal sites. If pheochromocytoma is detected in time and removed surgically, the prognosis is promising. ${ }^{94,95}$ LC3-I/II is an autophagy marker, whose content reflects autophagy levels. MA treatment showed a stimulatory effect on LC3-I/II conversion of rat pheochromocytoma PC12 cells, suggesting MA inhibited pheochromocytoma by promoting autophagy. ${ }^{96}$

Neuroblastoma is a malignant tumor originating from the sympathetic nerve, which is common in children and has a poor prognosis. MA $(0,10,40$, and $80 \mu \mathrm{M})$ significantly suppressed proliferation of SHSY-5Y neuroblastoma cells, which was dose and time dependent. In addition, MA can inhibit cell migration and invasion. ${ }^{97}$

MA can also inhibit soft tissue sarcomas (STS). As a single agent, MA inhibited cell proliferation in a dosedependent manner, with $\mathrm{IC}_{50}$ values of $45.3 \mu \mathrm{M}$ (SW982 cells) and $59.1 \mu \mathrm{M}$ (SK-UT-1 cells) in both STS cells. Inhibition rates of $\mathrm{MA} 80 \mu \mathrm{M}$ against the two cell lines were $70.3 \pm 1.1 \%$ and $68.8 \pm 1.5 \%$, respectively. Moreover, when MA was combined with doxorubicin, MA significantly improved the anti-tumor effects of doxorubicin by inhibiting cell viability and inducing cell death. For both STS cell lines, MA combined with doxorubicin facilitated the antiproliferative effect of doxorubicin by 1.3-2.3 times. ${ }^{98}$

\section{Derivatives}

Identifying new cytotoxic agents to enhance or restore apoptosis of malignant cancer cells is essential for more effective anti-cancer drugs. ${ }^{99}$ The $\mathrm{IC}_{50}$ values of $\mathrm{MA}$ in many cancer cell lines mentioned above are larger than 10 
micromolar. By structural modification, a series of MA bioavailability and solubility, are improved in derivatives. derivatives can ameliorate $\mathrm{IC}_{50}$ values on cancer cells. Many MA derivatives have anti-cancer effects and part of Further, other drug-related properties, such as their structures is shown in Figure 3.

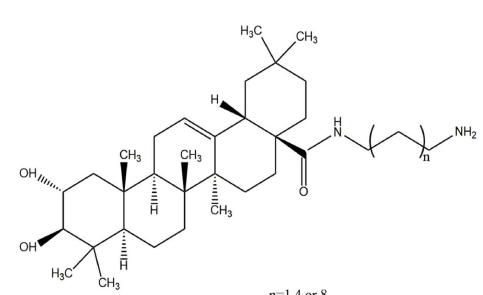

1

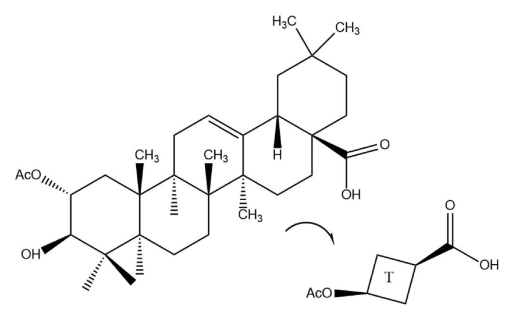

$3 \mathrm{a}$

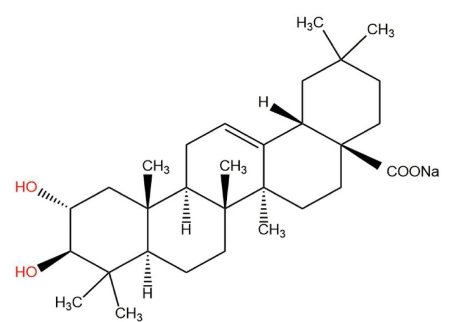

4a

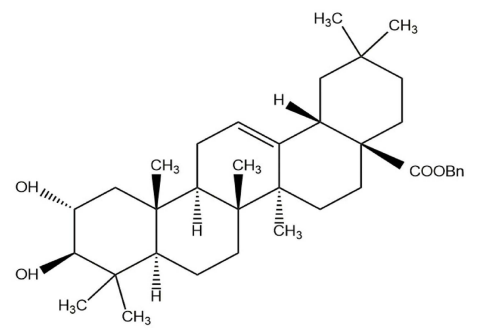

$4 \mathrm{~d}$

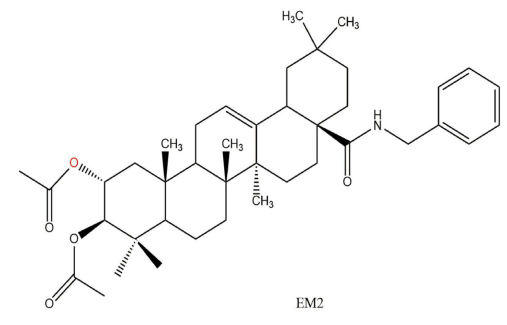

7

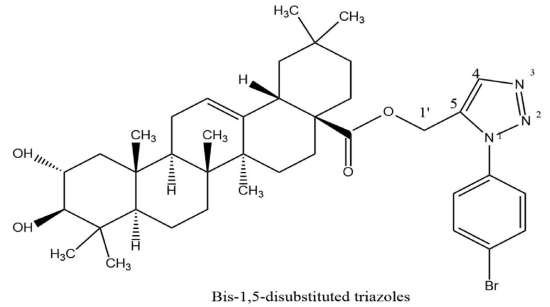

2a

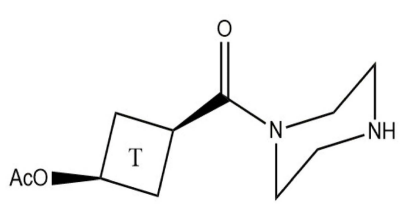

$3 b$

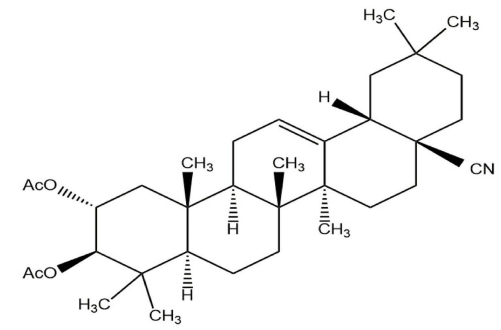

$4 \mathrm{~b}$

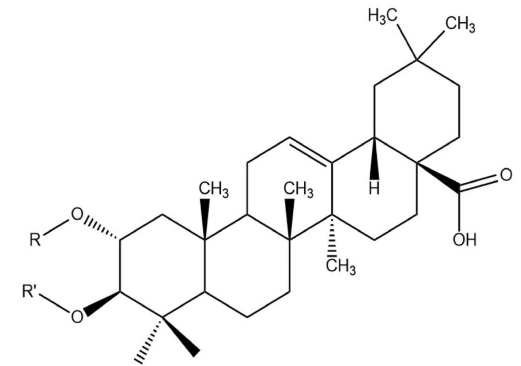

a $R=\left(2\right.$-fluorobenzoyl), $\mathrm{R}^{\prime}=\mathrm{H} \quad \mathrm{d} \mathrm{R}=\left(3,5\right.$-dinitrobenzoyl), $\mathrm{R}^{\prime}=\mathrm{H}$ b R=H, $\mathrm{R}^{\prime}=\left(2\right.$-fluorobenzoyl) $\quad$ e $\mathrm{R}=\mathrm{H}, \mathrm{R}^{\prime}=(3,5$-dinitrobenzoyl) c $R=\left(2\right.$-chlorobenzoyl), $R^{\prime}=H \quad f R=$ benzoyl, $R^{\prime}=H$

5

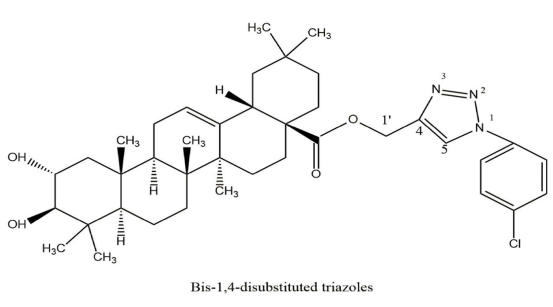

$2 b$

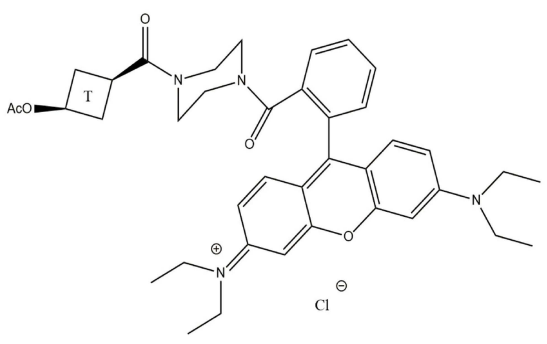

$3 \mathrm{c}$

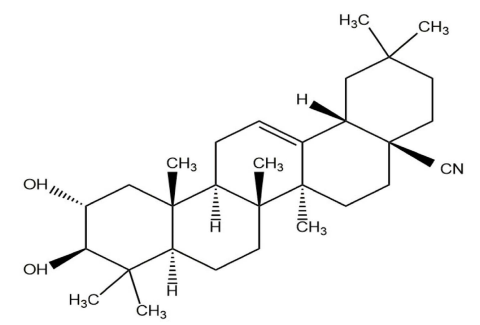

$4 \mathrm{c}$

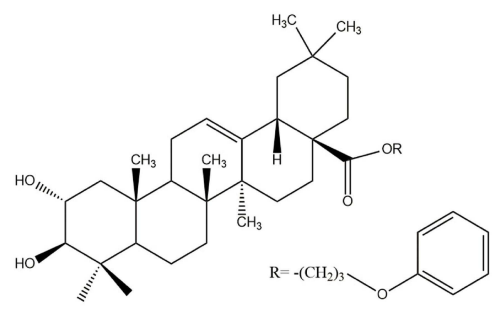

6

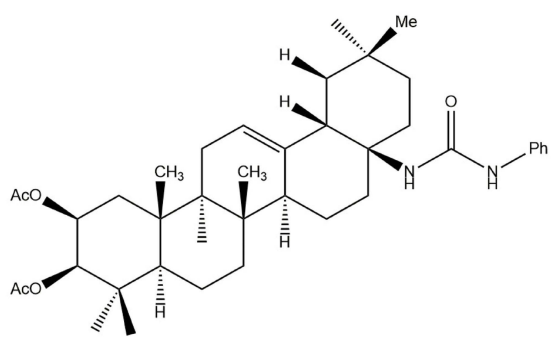

8

Figure 3 Chemical structure of MA derivatives. 
PEG polymer is considered a strong candidate for prodrug conjugation due to its high aqueous solubility. ${ }^{100}$ Experiments by Medina-O'Donnell et al showed that diamine and PEGylated-diamine derivatives of MA 1 have considerable anti-cancer potential. In non-tumor HPF cell lines, the cell viability range of all diamine conjugates of MA was $81 \%$ and $94 \%$. In tumor cell lines, the MA diamine conjugate with the shortest and longest diamine chain shows the best cytotoxic effects $\left(\mathrm{IC}_{50}\right.$ values from $0.76 \mu \mathrm{M}$ to $1.76 \mu \mathrm{M})$. In B16-F10 cell lines, they were 140- and 20-fold more effective than their corresponding precursors. ${ }^{101}$ Chouaib et al tested the anti-proliferative effects of MA and its 24 synthetic triazole derivatives on mouse EMT-6 (Breast) and human SW480 (Colon) cancer cell lines, showing that MA has significant antiproliferation effects on EMT-6 and SW480 cancer cells, with cell survival rates of $5 \%$ and $9 \%(100 \mu \mathrm{M})$, respectively. The proliferation experiment of its derivatives demonstrated in most cases 1.4-regioisomers type presented better anti-proliferative activity compared with 1.5-regioisomers type, Compound 2a displayed the most activity in this series against EMT- 6 and SW480, with a cell viability of $13 \%$ and $34 \%(100 \mu \mathrm{M})$. For the 1.4-regioisomers, compound $\mathbf{2 b}$ was the most active against both EMT-6 and SW480, with a cell viability of $6 \%$ and $10 \%(30 \mu \mathrm{M})$. This activity may be explained by the aryl group attaching to the triazole in relation to the triterpene moiety in cellular space. ${ }^{102}$

MA acetylation produced acetates 3a. Reaction of 3a with oxalyl chloride, followed by a reaction with piperazine, furnished amides $\mathbf{3 b}$, after which a reaction of rhodamine B with $\mathbf{3 b}$ produced violet-colored compounds $\mathbf{3 c}$. As a result, compound $\mathbf{3 c}$ is approximately 1000 -fold more cytotoxic than parent $\mathrm{MA}$, and the selectivity $\mathrm{F}_{\mathrm{Si}}$ (defined as $\mathrm{EC}_{50} \mathrm{~A} 2780$ tumor cell line compared with $\mathrm{EC}_{50}$ nonmalignant mouse fibroblasts NIH 3T3) increased by 50 . Here, rhodamine B is not cytotoxic (up to a concentration of $30 \mu \mathrm{M})$. Therefore, to the best of our knowledge, compound $\mathbf{3} \mathbf{c}$ is the most toxic triterpenoic acid derivative to date of cytotoxic compounds in nano-molar concentrations, where its cytotoxicity is comparable to commercial and well-established cytotoxic therapeutics, such as doxorubicin or paclitaxel. ${ }^{103}$

Parra et al showed that MA and its derivatives can suppress B16F10 melanoma cell growth by inducing apoptosis. MA was transformed into the corresponding sodium salt derivative 4a via several steps. In addition, the diacetyl derivative of MA was converted into the corresponding amide derivative first with thionyl chloride/DCM, then with $\mathrm{MeOH} / \mathrm{NH} 3$, then converted into nitrile derivative 4b via treatment with thionyl chloride in DCM, which was further deacetylated to form compound $\mathbf{4 c}$. Moreover, 28-benzyl maslinic acid $\mathbf{4 d}$, a derivative of MA treated with benzyl chloride and DMF, also showed significant anticancer effects. The details are as follows. At a concentration of $1 \mu \mathrm{M}$, the pro-apoptotic activities of some compounds were sodium maslinate $4 \mathbf{a}$ at $56.67 \%$, 2.3-diacetoxy-28-cyanide $\mathbf{4 b}$ at $68.62 \%, 28$-cyanide $\mathbf{4 c}$ at $78.75 \%$, and 28 -benzoyl $4 \mathbf{d}$ at $87.50 \% .{ }^{99}$ Serbian et al reacted MA and benzoyl chlorides to form two corresponding acylated compounds, 2-O-acylated and 3-O-acylated MA derivatives. Biological screening of these compounds by SRB assays showed cancer cell cytotoxicity increased compared with MA. The $\mathrm{EC}_{50}$ value of A2780 cells treated with MA for $96 \mathrm{~h}$ was $19.5 \mu \mathrm{M}$. However, the $\mathrm{EC}_{50}$ values of compounds (5a-f) were all lower than $10 \mu \mathrm{M} .{ }^{104}$ Another experiment demonstrated that MA and MA analogue 6 showed cell membrane damaging activity in tumor cells. In A2780 cells, the $\mathrm{IC}_{50}$ values of $\mathrm{MA}$ and compounds were $19.5 \mu \mathrm{M}$ and $10.6 \mu \mathrm{M}$, respectively. The latter study showed that, during cell culture, compound 6 and cholesterol formed crystals around or near the cells. Compound $\mathbf{6}$ then entered the cell membrane and the lipid raft compacted cholesterol, altering the cell membrane, decreasing cell volume, and inducing apoptosis. ${ }^{105}$

Another study also demonstrated that MA and its acetylated derivative (7, EM2) showed significant antimelanoma effects. In 518A2 cells, MA showed an $\mathrm{IC}_{50}$ value of $13.7 \mu \mathrm{M}$, whereas 7 showed stronger toxicity with an $\mathrm{IC}_{50}$ value of $1.5 \mu \mathrm{M}$. In nonmalignant mouse fibroblasts $\left(\mathrm{NiH} 3 \mathrm{~T} 3\right.$ cell line), the $\mathrm{IC}_{50}$ value of 7 was $33.8 \mu \mathrm{M}^{106}$

Derivatization at position $\mathrm{C}-28$ of MA could improve anti-proliferative activity, where the $\mathrm{EC}_{50}$ of 2, 3-dio-acetyl-benzylamine 7 was $0.5 \mu \mathrm{M}$ in A2780 ovarian cancer cells. ${ }^{107}$ Structural modifications performed on 7 revealed the presence of these acetyl groups in $\mathbf{7}$ and the presence of $(2 b, 3 b)$-configurated centers are required for high cytotoxicity combined with optimal selectivity between malignant cells and non-malignant mouse fibroblasts. Therefore, maslinic acid derived N-[2b,3b-di -O-acetyl-17bamino-28-norolean-12-en-17-yl]-phenylurea 8 was synthesized by replacing the benzylamide function for a phenylurea moiety, which improved results with $\mathrm{EC}_{50}$ values of $0.9 \mu \mathrm{M}$ (for A2780 ovarian cancer cells) 
with $\mathrm{EC}_{50}>120 \mu \mathrm{M}$ for fibroblasts (NIH 3T3) and triggered apoptosis. ${ }^{108}$

\section{Discussion}

Bioactive compounds isolated from TCM, as well as derivatives, are becoming increasingly more promising as complementary and alternative medicines for cancer treatment. ${ }^{109-111} \mathrm{MA}$ is widely distributed in many traditional Chinese medicines, such as olive tree (Olea europaea L.), shanzha (Crataegus pinnatifida Bunge), hongzao (Ziziphus jujuba Mill.), and pipaye (Eriobotrya japonica Thunb.). The literature shows MA can inhibit proliferation, migration, and invasion of cancer cells, promote apoptosis and autophagy of cancer cells, and suppress tumor growth to alleviate secondary diseases caused by tumor in mice xenograft tumor models. Specifically, we found $\mathrm{IC}_{50}$ values of MA against various cancer cells were all lower than $60 \mu \mathrm{M}$. In lung cancer A549 cells, MA showed significant inhibitory effects at $21 \mu \mathrm{M}$. In colon cancer HT29 cells, MA showed an $\mathrm{IC}_{50}$ value for $24 \mathrm{~h}$ at 61 $\mu \mathrm{M}$. In addition, for melanoma $518 \mathrm{~A} 2$ cells, the $\mathrm{IC}_{50}$ value of MA was $13.7 \mu \mathrm{M}$, and when acting on $\mathrm{GC}$ MKN28 cells, the $\mathrm{IC}_{50}$ value was less than $10 \mu \mathrm{M}$. Further, different doses of MA $(2.5,5$, and $10 \mu \mathrm{M})$ combined with docetaxel in MDA-MB-231 cells significantly increased sensitivity of MDA-MB-231 cells to docetaxel in a dose-dependent manner. ${ }^{65}$ Similarly, MA can increase the proliferation inhibitory effect of TNF- $\alpha$ on pancreatic cancer cells, which was significant at concentrations of 1.5 $\mu \mathrm{M} .{ }^{112}$ In addition, MA can inhibit tumor growth in mouse xenograft tumor models and reduce secondary diseases caused by tumors. In summary, MA inhibited proliferation of various tumor cells and showed lower $\mathrm{IC}_{50}$ values in melanoma 518A2 cells and gastric cancer MKN28 cells compared with other cell lines. When applied with marketed chemotherapeutic drugs, MA could significantly increase sensitivity and promote anti-cancer effects.

MA and its derivatives have gained attention as dietary supplements and its efficacy as a functional food or medicine cannot be established without bioavailability studies. ${ }^{113}$ Male Sprague-Dawley rats were orally administered MA at 1,2 , and $5 \mathrm{mg} / \mathrm{kg}$. MA was then detected two days later in the jejunum, ileum, cecum, and colon segments, with the highest concentrations in the distal part of the intestine. In addition, eleven gut-derived metabolites formed by mono-, dihydroxylation, and dehydrogenation reactions were identified, suggesting MA undergoes Phase I reactions resulting in most monohydroxylated metabolites without the presence of Phase II derivatives. ${ }^{114}$ Another study also proved that MA has relative rapid oral absorption, with a peak concentration after $50 \mathrm{mg} / \mathrm{kg}$ oral administration at $0.51 \mathrm{~h}$ and a bioavailability of $5.13 \%$. After entering the bloodstream, it is widely distributed in the tissues, since the central and peripheral distribution volumes were $8.41 \mathrm{~L} / 70 \mathrm{~kg}$ and 63.6 $\mathrm{L} / 70 \mathrm{~kg}$, respectively. The clearance $(8 \mathrm{~L} / \mathrm{h} / 70 \mathrm{~kg})$ was related to unaltered renal excretion. ${ }^{115}$ Although based on Cmax $(32.8 \pm 10.4)$ and AUC0-10 (185.1 \pm 66.5$)$, the bioavailability of MA was 7-fold higher than similar structure oleanolic acids, ${ }^{116}$ clinical application of MA is still limited by solubility and source.

Current studies show anti-tumor activity of MA is related to its inhibition of proliferation, promotion of apoptosis, regulation of autophagy, and inhibition of angiogenesis (Figure 4). MA induces apoptosis via both extrinsic and intrinsic apoptotic pathways. First, MA can promote activation of caspase- 8 and caspase- 3 , which further decreases Bcl-2 expression and increases Bid cleavage levels. Conversely, MA promoted expression of Smac, inhibited expression of c-IAP1, c-IAP2, XIAP, and survivin, activated caspase -9 , and promoted the release of mitochondrial cytochrome $\mathrm{C}$ to eventually trigger cell apoptosis. The MAPK pathway is constituted by the ERK1/2 MAPK family, P38 MAPK family, and JNK/SAPK MAPK family. The ERK1/2 signaling pathway is the first RasRaf-MAPK classic signal transduction pathway, which is most closely related to cell proliferation. MA treatment can inhibit expression of major proteins in the ERK pathway, leading to apoptosis of cancer cells. In addition, MA activates the p38 MAPK signaling pathway by promoting $[\mathrm{Ca} 2+] \mathrm{i}$ activity, then activates Caspase-3 to stimulate apoptosis. ${ }^{117}$ Furthermore, JNK may act directly upon the Bcl-2 protein family, thus inducing the mitochondrial pathway, as well as stimulate Bid. Bid-active targets the mitochondria to modulate other Bcl-2-like factors, such as Bax, ${ }^{118,119}$ and MA treatment induces expression of JNK in cells, thereby activating $\mathrm{p} 53$ to promote cytochrome $\mathrm{C}$ release and increase caspase- $9,-3$, and -7 expression, leading to apoptosis. ERK1/2 activation can trigger STAT3, leading to gene expression that controls critical cellular functions, including cell proliferation, survival, differentiation, and development. IL-6 is a pleiotropic cytokine that plays an important role in tumor development by regulating immune and inflammatory responses and can participate in cell proliferation, differentiation, 


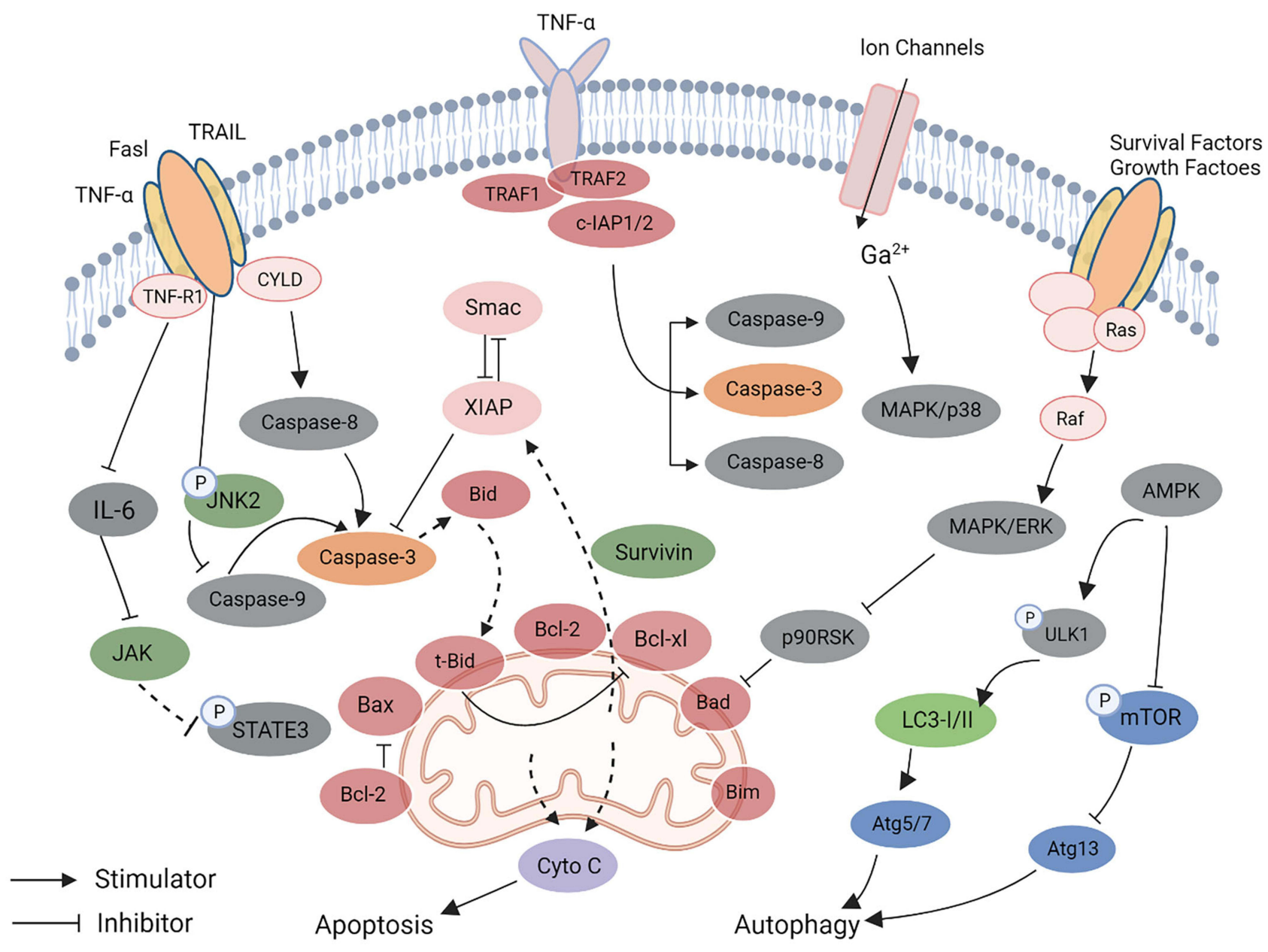

Figure 4 Partial molecular pathways involved in the anti-cancer mechanism of MA. Note: Created with BioRender.com.

apoptosis, and metastasis. ${ }^{120}$ IL-6 may activate the Janus kinase (JAK)/signal transducer and activator of STAT3 signaling pathway, as well as the MAPK signaling pathway. ${ }^{121-123}$ Further, MA treatment can inhibit phosphorylated-STAT3 and JAK2 expression to decrease IL-6 protein levels. These results indicate MA inhibits growth of cancer cells when inducing apoptosis by suppressing the IL-6/JAK/STAT3 signaling cascade.

\section{Conclusion and Perspective}

Herein, we summarized the anti-cancer effects and mechanisms of MA and its derivatives. MA can inhibit lung cancer, colorectal cancer, breast cancer, bladder cancer, leukemia, lymphoma, melanoma, and prostate cancer, among others. The anti-cancer effect of MA is mainly related to inducing cell apoptosis, but also to inducing cell cycle arrest, regulation of autophagy, and hindering angiogenesis. However, it is clear the anticancer mechanisms of MA are not sufficiently explained. Most studies are in vitro experiments, while in vivo experiments are inadequate, which requires further research. In vitro, MA showed antiproliferative effects in HCT116, SW480, Caco-2, and Raji cells, among others. Nevertheless, MA showed high $\mathrm{IC}_{50}$ values within various cells. A series of derivatives obtained by modifying the MA structure show high cytotoxicity to human tumor cell lines, but low cytotoxicity to non-malignant cells. However, we find that the dose-effect relationship, toxicity and safety of MA and its derivatives is still obviously inadequate, which requires more in-depth and comprehensive study.

In summary, MA and its derivatives show inhibitory effects on a variety of tumors and are expected to become candidate anti-tumor agents in the future. 


\section{Acknowledgments}

This work was supported by the National Natural Science Foundation of China: Study on the property-efficacy Relationship of Traditional Chinese Medicine (No.81891012); the National Natural Science Foundation of China: Study on the authenticity of traditional Chinese medicine (NO.81891010); the Outstanding Talents Fund of Double First-Class initiative Construction of Chengdu University of TCM (2020XSGG001); Funds for the Central Universities (No. YJ201880), and National Natural Science Foundation of China (Nos. 82003879), the Key Project of Science and Technology Department of Sichuan Province (No. 20ZDYF3092); and the Youth Talent Promotion Project of China Association for Science and Technology (CACM-2020-QNRC1-01).

\section{Disclosure}

The authors declare no conflicts of interest for this work.

\section{References}

1. Tewari D, Patni P, Bishayee A, Sah AN, Bishayee A. Natural products targeting the PI3K-Akt-mTOR signaling pathway in cancer: a novel therapeutic strategy. Semin Cancer Biol. 2019: S1044-579X(19)30405-5. doi:10.1016/j.semcancer.2019.12.008

2. Finkel T, Serrano M, Blasco M. The common biology of cancer and ageing. Nature. 2007;448(7155):767-774. doi:10.1038/nature05985

3. Martinez-Gonzalez M, Estruch R. Mediterranean diet, antioxidants and cancer: the need for randomized trials. Eur J Cancer Prev. 2004;13(4):327-335. doi:10.1097/01.cej.0000137512.71845.bf

4. Farras M, Almanza-Aguilera E, Hernaez A, et al. Beneficial effects of olive oil and Mediterranean diet on cancer physio-pathology and incidence. Semin Cancer Biol. 2021;73:178-195. doi:10.1016/j.semcancer.2020.11.011

5. Kroemer G, Pouyssegur J. Tumor cell metabolism: cancer's achilles' heel. Cancer Cell. 2008;13(6):472-482. doi:10.1016/j. ccr.2008.05.005

6. Liu Y, Yang S, Wang K, et al. Cellular senescence and cancer: focusing on traditional Chinese medicine and natural products. Cell Prolif. 2020;53(10):12894. doi:10.1111/cpr.12894

7. Huang A, Garraway LA, Ashworth A, Weber B. Synthetic lethality as an engine for cancer drug target discovery. Nat Rev Drug Discov. 2020;19(1):23-38. doi:10.1038/s41573-019-0046-Z

8. Fang Y, Yang C, Yu Z, et al. Natural products as LSD1 inhibitors for cancer therapy. Acta Pharm Sin B. 2020;11(3):621-631. doi:10.1016/j.apsb.2020.06.007

9. Yang Z, Zhang Q, Yu L, Zhu J, Cao Y, Gao X. The signaling pathways and targets of traditional Chinese medicine and natural medicine in triple-negative breast cancer. J Ethnopharmacol. 2021;264:113249. doi:10.1016/j.jep.2020.113249

10. Andrijauskaite K, Wargovich MJ. Role of natural products in breast cancer related symptomology: targeting chronic inflammation. Semin Cancer Biol. 2020:S1044-579X(20)30183-8.

11. Wang D, Huang J, Gui T, et al. SR-BI as a target of natural products and its significance in cancer. Semin Cancer Biol. 2020;11:S1044-579X(19)30425-0.

12. Shinde $P$, Banerjee $P$, Mandhare A. Marine natural products as source of new drugs: a patent review (2015-2018). Expert Opin Ther Pat. 2019;29(4):283-309. doi:10.1080/13543776.2019.1598972
13. Newman DJ, Cragg GM. Natural products as sources of new drugs from 1981 to 2014. J Nat Prod. 2016;79(3):629-661. doi:10.1021/acs.jnatprod.5b01055

14. Falev DI, Kosyakov DS, Ul'yanovskii NV, Ovchinnikov DV. Rapid simultaneous determination of pentacyclic triterpenoids by mixed-mode liquid chromatography-tandem mass spectrometry. J Chromatogr A. 2020;1609:460458. doi:10.1016/ j.chroma.2019.460458

15. Jager S, Trojan H, Kopp T, Laszczyk MN, Scheffler A. Pentacyclic triterpene distribution in various plants - rich sources for a new group of multi-potent plant extracts. Molecules. 2009;14(6):2016-2031. doi:10.3390/molecules 14062016

16. Jung B, Chung J, Zhou W, Lee T, Na M, Bae JS. Inhibitory effects of pentacyclic triterpenoids from Astilbe rivularis on TGFBIp-induced inflammatory responses in vitro and in vivo. Chem Biol Interact. 2016;254:179-190. doi:10.1016/j.cbi.2016.06.015

17. Han JH, Zhou W, Li W, et al. Pentacyclic triterpenoids from Astilbe rivularis that enhance glucose uptake via the activation of Akt and Erk1/2 in C2C12 Myotubes. J Nat Prod. 2015;78 (5):1005-1014. doi:10.1021/np5009174

18. Peragon J, Rufino-Palomares EE, Munoz-Espada I, Reyes-Zurita FJ, Lupianez JA, New A. HPLC-MS method for measuring maslinic acid and oleanolic acid in HT29 and HepG2 human cancer cells. Int $J$ Mol Sci. 2015;16(9):21681-21694. doi:10.3390/ijms160921681

19. Peragon J. Time course of pentacyclic triterpenoids from fruits and leaves of olive tree (Olea europaea L.) cv. Picual and cv. Cornezuelo during ripening. J Agric Food Chem. 2013;61 (27):6671-6678. doi:10.1021/jf401495t

20. Sun M, Tang Y, Ding T, Liu M, Wang X. Investigation of cytochrome $\mathrm{P} 450$ inhibitory properties of maslinic acid, a bioactive compound from Olea europaea L., and its structure-activity relationship. Phytomedicine. 2015;22(1):56-65. doi:10.1016/j.phymed.2014.10.003

21. Siewert B, Pianowski E, Csuk R. Esters and amides of maslinic acid trigger apoptosis in human tumor cells and alter their mode of action with respect to the substitution pattern at C-28. Eur J Med Chem. 2013;70:259-272. doi:10.1016/j.ejmech.2013.10.016

22. Chen $Y$, Yan $D, W u ~ C$, et al. Maslinic acid prevents IL-1 $\beta$ induced inflammatory response in osteoarthritis via PI3K/AKT/ NF-кB pathways. J Cell Physiol. 2021;236(3):1939-1949. doi:10.1002/jcp.29977

23. Nagai N, Yagyu S, Hata A, et al. Maslinic acid derived from olive fruit in combination with resistance training improves muscle mass and mobility functions in the elderly. J Clin Biochem Nutr. 2019;64(3):224-230. doi:10.3164/jcbn.18-104

24. Lee W, Kim J, Park EK, Bae J-S. Maslinic acid ameliorates inflammation via the downregulation of NF- $\kappa \mathrm{B}$ and STAT-1. Antioxidants. 2020;9(2):106.

25. Kim K, Kim J, Baek M, Bae J. Novel factor Xa inhibitor, maslinic acid, with antiplatelet aggregation activity. J Cell Physiol. 2020;235(12):9445-9456. doi:10.1002/jcp.29749

26. Pavel I, Csuk R, Danciu C, et al. Assessment of the antiangiogenic and anti-inflammatory properties of a maslinic acid derivative and its potentiation using zinc chloride. Int $J$ Mol Sci. 2019;20(11):2828. doi:10.3390/ijms20112828

27. Phang S, Ooi B, Ahemad N, Yap W. Maslinic acid suppresses macrophage foam cells formation: regulation of monocyte recruitment and macrophage lipids homeostasis. Vascul Pharmacol. 2020;128:106675.

28. Liu Y, Kong C, Song P, Zhou H, Zhao X, Tang Q. Maslinic acid protects against pressure overload-induced cardiac hypertrophy in mice. J Pharmacol Sci. 2018;138(2):116-122.

29. Lee W, Lee H, Lee T, Park E, Bae J. Inhibitory functions of maslinic acid, a natural triterpene, on HMGB1-mediated septic responses. Phytomedicine. 2020;69:153200. 
30. Blanco-Cabra N, Vega-Granados K, Moya-Andérico L, et al. Novel oleanolic and maslinic acid derivatives as a promising treatment against bacterial biofilm in nosocomial infections: an in vitro and in vivo study. ACS Infect Dis. 2019;5(9):1581-1589.

31. Liou C, Dai Y, Wang C, Fang L, Huang W. Maslinic acid protects against obesity-induced nonalcoholic fatty liver disease in mice through regulation of the Sirt1/AMPK signaling pathway. FASEB J. 2019;33(11):11791-11803.

32. Hung Y, Yang H, Yin M. Asiatic acid and maslinic acid protected heart via anti-glycative and anti-coagulatory activities in diabetic mice. Food Funct. 2015;6(9):2967-2974.

33. Mkhwanazi B, van Heerden F, Mavondo G, Mabandla M, Musabayane C. Triterpene derivative improves the renal function of streptozotocin-induced diabetic rats: a follow-up study on maslinic acid. Ren Fail. 2019;41(1):547-554.

34. Vasudevan A, Baruah PS, Smith JC, et al. Single-chromosomal gains can function as metastasis suppressors and promoters in colon cancer. Dev Cell. 2020;52(4):413-28 e6. doi:10.1016/j. devcel.2020.01.034

35. Li Y, Bai L, Yu H, et al. Epigenetic inactivation of alpha-internexin accelerates microtubule polymerization in colorectal cancer. Cancer Res. 2020;80(23):5203-5215. doi:10.1158/ 0008-5472.CAN-20-1590

36. Walter V, Boakye D, Weberpals J, et al. Decreasing use of chemotherapy in older patients with stage III Colon cancer irrespective of comorbidities. J Natl Compr Canc Netw. 2019;17 (9):1089-1099.

37. Cheng B, Rong A, Zhou Q, Li W. LncRNA LINC00662 promotes colon cancer tumor growth and metastasis by competitively binding with miR-340-5p to regulate CLDN8/IL22 co-expression and activating ERK signaling pathway. $J$ Exp Clin Cancer Res. 2020;39(1):5. doi:10.1186/s13046-019-1510-7

38. Stoffel EM, Murphy CC. Epidemiology and mechanisms of the increasing incidence of colon and rectal cancers in young adults. Gastroenterology. 2020;158(2):341-353. doi:10.1053/j.gastro.2019. 07.055

39. Zhang Y, Kang M, Zhang B, et al. m(6)A modification-mediated CBX8 induction regulates stemness and chemosensitivity of colon cancer via upregulation of LGR5. Mol Cancer. 2019;18 (1):185. doi:10.1186/s12943-019-1116-x

40. Juan ME, Lozano-Mena G, Sanchez-Gonzalez M, Planas JM. Reduction of preneoplastic lesions induced by 1,2-dimethylhydrazine in rat colon by maslinic acid, a pentacyclic triterpene from Olea europaea L. Molecules. 2019;24(7):1266. doi:10.3390/molecules24071266

41. Sanchez-Tena S, Reyes-Zurita FJ, Diaz-Moralli S, et al. Maslinic acid-enriched diet decreases intestinal tumorigenesis in Apc(Min/ +) mice through transcriptomic and metabolomic reprogramming. PLoS One. 2013;8(3):e59392. doi:10.1371/journal.pone.0059392

42. Wei Q, Zhang B, Li P, Wen X, Yang J. Maslinic acid inhibits colon tumorigenesis by the AMPK-mTOR signaling pathway. J Agric Food Chem. 2019;67(15):4259-4272. doi:10.1021/acs.jafc.9b00170

43. Reyes-Zurita FJ, Rufino-Palomares EE, Medina PP, et al. Antitumour activity on extrinsic apoptotic targets of the triterpenoid maslinic acid in p53-deficient Caco-2 adenocarcinoma cells. Biochimie. 2013;95 (11):2157-2167. doi:10.1016/j.biochi.2013.08.017

44. Reyes-Zurita FJ, Rufino-Palomares EE, Garcia-Salguero L, et al. Maslinic acid, a natural triterpene, induces a death receptor-mediated apoptotic mechanism in caco-2 p53-deficient colon adenocarcinoma cells. PLoS One. 2016;11(1):e0146178. doi:10.1371/journal.pone.0146178

45. Reyes-Zurita FJ, Rufino-Palomares EE, Lupianez JA, Cascante M. Maslinic acid, a natural triterpene from Olea europaea L., induces apoptosis in HT29 human colon-cancer cells via the mitochondrial apoptotic pathway. Cancer Lett. 2009;273 (1):44-54. doi:10.1016/j.canlet.2008.07.033
46. Rufino-Palomares EE, Reyes-Zurita FJ, Garcia-Salguero L, et al. Maslinic acid, a triterpenic anti-tumoural agent, interferes with cytoskeleton protein expression in HT29 human colon-cancer cells. J Proteomics. 2013;83:15-25. doi:10.1016/j.jprot.2013.02. 031

47. Landi MT, Bishop DT, MacGregor S, et al. Genome-wide association meta-analyses combining multiple risk phenotypes provide insights into the genetic architecture of cutaneous melanoma susceptibility. Nat Genet. 2020;52(5):494-504. doi:10.1038/ s41588-020-0611-8

48. Chang YM, Newton-Bishop JA, Bishop DT, et al. A pooled analysis of melanocytic nevus phenotype and the risk of cutaneous melanoma at different latitudes. Int J Cancer. 2009;124 (2):420-428. doi:10.1002/ijc.23869

49. Mokhtari K, Rufino-Palomares EE, Perez-Jimenez A, et al. Maslinic acid, a triterpene from olive, affects the antioxidant and mitochondrial status of B16F10 melanoma cells grown under stressful conditions. Evid Based Complement Alternat Med. 2015;2015:272457. doi:10.1155/2015/272457

50. Mokhtari K, Perez-Jimenez A, Garcia-Salguero L, Lupiáñez J, RufinoPalomares EE. Unveiling the differential antioxidant activity of maslinic acid in murine melanoma cells and in rat embryonic healthy cells following treatment with hydrogen peroxide. Molecules. 2020;25 (17):4020. doi:10.3390/molecules25174020

51. Chiba S, Sakata-Yanagimoto M. Advances in understanding of angioimmunoblastic T-cell lymphoma. Leukemia. 2020;34 (10):2592-2606. doi:10.1038/s41375-020-0990-y

52. Hsum YW, Yew WT, Hong PL, et al. Cancer chemopreventive activity of maslinic acid: suppression of COX-2 expression and inhibition of NF- $\mathrm{KB}$ and AP-1 activation in raji cells. Planta Med. 2011;77(2):420-428. doi:10.1055/s-0030-1250203

53. Yap WH, Khoo KS, Lim SH, Yeo CC, Lim YM. Proteomic analysis of the molecular response of raji cells to maslinic acid treatment. Phytomedicine. 2012;19(2):183-191. doi:10.1016/j. phymed.2011.08.058

54. Jian Y, Zhao M, Cao J, et al. A gastric cancer peptide GX1-modified nano-lipid carriers encapsulating paclitaxel: design and evaluation of anti-tumor activity. Drug Des Devel Ther. 2020;14:2355-2370. doi:10.2147/DDDT.S233023

55. The L. Lung cancer: some progress, but still a lot more to do Lancet. 2019;394(10212):P1880.

56. Hamann HA, Ver Hoeve ES, Carter-Harris L, Studts JL, Ostroff JS. Multilevel opportunities to address lung cancer stigma across the cancer control continuum. J Thorac Oncol. 2018;13 (8):1062-1075. doi:10.1016/j.jtho.2018.05.014

57. Varghese AM, Zakowski MF, Yu HA, et al. Small-cell lung cancers in patients who never smoked cigarettes. J Thorac Oncol. 2014;9(6):892-896. doi:10.1097/JTO.0000000000000142

58. Bai X, Zhang Y, Jiang H, et al. Effects of maslinic acid on the proliferation and apoptosis of A549 lung cancer cells. Mol Med Rep. 2016;13(1):117-122. doi:10.3892/mmr.2015.4552

59. Hsia TC, Liu WH, Qiu WW, Luo J, Yin MC. Maslinic acid induces mitochondrial apoptosis and suppresses HIF-1alpha expression in A549 lung cancer cells under normoxic and hypoxic conditions. Molecules. 2014;19(12):19892-19906. doi:10.3390/ molecules191219892

60. Vajhadin F, Ahadian S, Travas-Sejdic J, et al. Electrochemical cytosensors for detection of breast cancer cells. Biosens Bioelectron. 2020;151:111984. doi:10.1016/j.bios.2019.111984

61. Chen B, Lai J, Dai D, Chen R, Li X, Liao N. JAK1 as a prognostic marker and its correlation with immune infiltrates in breast cancer. Aging. 2019;11(23):11124-11135.

62. Umeh-Garcia M, Simion C, Ho PY, et al. A novel bioengineered miR-127 prodrug suppresses the growth and metastatic potential of triple-negative breast cancer cells. Cancer Res. 2020;80 (3):418-429. doi:10.1158/0008-5472.CAN-19-0656 
63. Weng W, Goel A. Curcumin and colorectal cancer: an update and current perspective on this natural medicine. Semin Cancer Biol. 2020. doi:10.1016/j.semcancer.2020.02.011

64. Jain R, Grover A. Maslinic acid differentially exploits the MAPK pathway in estrogen-positive and triple-negative breast cancer to induce mitochondrion-mediated, caspase-independent apoptosis. Apoptosis. 2020;25(11-12):817-834. doi:10.1007/s10495-02001636-y

65. Wang K, Zhu X, Yin Y. Maslinic acid enhances docetaxel response in human docetaxel-resistant triple negative breast carcinoma MDA-MB-231 cells via regulating MELK-FoxM1ABCB1 signaling cascade. Front Pharmacol. 2020;11:835. doi:10.3389/fphar.2020.00835

66. Seidlitz T, Chen Y, Uhlemann H, et al. Mouse models of human gastric cancer subtypes with stomach-specific CreERT2-mediated pathway alterations. Gastroenterology. 2019;157(6):1599-614.e2.

67. Gantuya B, Oyuntsetseg K, Bolor D, et al. Evaluation of serum markers for gastric cancer and its precursor diseases among high incidence and mortality rate of gastric cancer area. Gastric Cancer. 2019;22(1):104-112. doi:10.1007/s10120-018-0844-8

68. Liu X, Cao Y, Li R, et al. Poor clinical outcomes of intratumoral dendritic cell-specific intercellular adhesion molecule 3-grabbing non-integrin-positive macrophages associated with immune evasion in gastric cancer. Eur J Cancer. 2020;128:27-37.

69. Deng M, Liu B, Song H, et al. Beta-elemene inhibits the metastasis of multidrug-resistant gastric cancer cells through miR-1323/ Cbl-b/EGFR pathway. Phytomedicine. 2020;69:153184. doi:10.10 16/j.phymed.2020.153184

70. Wang D, Tang S, Zhang Q. Maslinic acid suppresses the growth of human gastric cells by inducing apoptosis via inhibition of the interleukin-6 mediated Janus kinase/signal transducer and activator of transcription 3 signaling pathway. Oncol Lett. 2017;13 (6):4875-4881. doi:10.3892/ol.2017.6073

71. Ye Z, Zhuo Q, Hu Q, et al. FBW7-NRA41-SCD1 axis synchronously regulates apoptosis and ferroptosis in pancreatic cancer cells. Redox Biol. 2020;38:101807. doi:10.1016/j.redox.2020.101807

72. Mizrahi J, Surana R, Valle J, Shroff RJL. Pancreatic cancer. Lancet. 2020;395(10242):2008-2020.

73. Tian Y, Xu H, Farooq AA, et al. Maslinic acid induces autophagy by down-regulating HSPA8 in pancreatic cancer cells. Phytother Res. 2018;32(7):1320-1331. doi:10.1002/ptr.6064

74. Cruceriu D, Baldasici O, Balacescu O, Berindan-Neagoe I. The dual role of tumor necrosis factor-alpha (TNF- $\alpha$ ) in breast cancer: molecular insights and therapeutic approaches. Cell Oncol. 2020;43(1):1-18.

75. Li C, Yang Z, Zhai $\mathrm{C}$, et al. Maslinic acid potentiates the anti-tumor activity of tumor necrosis factor alpha by inhibiting NF-kappaB signaling pathway. Mol Cancer. 2010;9:73.

76. Wang $\mathrm{X}$, Zhang $\mathrm{R}$, Wu S, et al. Super-enhancer LncRNA LINC00162 promotes progression of bladder cancer. Iscience. 2020;23(12):101857.

77. Zhang S, Ding D, Zhang X, Shan L, Liu Z. Maslinic acid induced apoptosis in bladder cancer cells through activating p38 MAPK signaling pathway. Mol Cell Biochem. 2014;392(1-2):281-287. doi:10.1007/s11010-014-2038-y

78. Lai KC, Lu HF, Chen KB, et al. Casticin promotes immune responses, enhances macrophage and $\mathrm{NK}$ cell activities, and increases survival rates of leukemia BALB/c mice. Am J Chin Med. 2019;47(1):223-236. doi:10.1142/S0192415X19500113

79. Uto T, Sakamoto A, Tung NH, et al. Anti-proliferative activities and apoptosis induction by triterpenes derived from Eriobotrya japonica in human leukemia cell lines. Int J Mol Sci. 2013;14 (2):4106-4120. doi:10.3390/ijms14024106

80. Lai KC, Peng SF, Liu CC, et al. Maslinic acid enhances immune responses in leukemic mice through macrophage phagocytosis and natural killer cell activities in vivo. In Vivo. 2019;33 (1):65-73. doi:10.21873/invivo. 11440
81. Davidsson S, Andren O, Ohlson AL, et al. FOXP3(+) regulatory $\mathrm{T}$ cells in normal prostate tissue, postatrophic hyperplasia, prostatic intraepithelial neoplasia, and tumor histological lesions in men with and without prostate cancer. Prostate. 2018;78 (1):40-47. doi: $10.1002 /$ pros. 23442

82. Lorenzo G, Hughes TJR, Dominguez-Frojan P, Reali A, Gomez H. Computer simulations suggest that prostate enlargement due to benign prostatic hyperplasia mechanically impedes prostate cancer growth. Proc Natl Acad Sci U S A. 2019;116 (4):1152-1161. doi:10.1073/pnas.1815735116

83. Kwon G, Cho H, Chung W, Park K, Moon A, Park J. Isoliquiritigenin inhibits migration and invasion of prostate cancer cells: possible mediation by decreased JNK/AP-1 signaling. J Nutr Biochem. 2009;20(9):663-676.

84. Park SY, Nho CW, Kwon DY, Kang YH, Lee KW, Park JH. Maslinic acid inhibits the metastatic capacity of DU145 human prostate cancer cells: possible mediation via hypoxia-inducible factor-1alpha signalling. $B r \quad J \quad$ Nutr. 2013;109(2):210-222. doi:10.1017/S0007114512000967

85. Linehan WM, Schmidt LS, Crooks DR, et al. The metabolic basis of kidney cancer. Cancer Discov. 2019;9(8):1006-1021. doi:10.1158/2159-8290.CD-18-1354

86. Richter AM, Woods ML, Kuster MM, et al. RASSF10 is frequently epigenetically inactivated in kidney cancer and its knockout promotes neoplasia in cancer prone mice. Oncogene. 2020;39 (15):3114-3127. doi:10.1038/s41388-020-1195-6

87. Thakor P, Song W, Subramanian RB, Thakkar VR, Vesey DA, Gobe GC. Maslinic acid inhibits proliferation of renal cell carcinoma cell lines and suppresses angiogenesis of endothelial cells. J Kidney Cancer VHL. 2017;4(1):16-24. doi:10.15586/jkcvhl.2017.64

88. Cao J, Chen M, Feng X, Shen J, Cai X. Comment on: comparison of oncological outcomes after open and laparoscopic re-resection of incidental gallbladder cancer. J Br Surg. 2020;107(6):771-772.

89. Pande S, Goyal D, Chowdhury Z, Dhal I. Gallbladder carcinoma presenting with elbow swelling. Clin Nucl Med. 2020;45(9): e413-e415.

90. Yu Y, Wang J, Xia N, Li B, Jiang X. Maslinic acid potentiates the antitumor activities of gemcitabine in vitro and in vivo by inhibit-

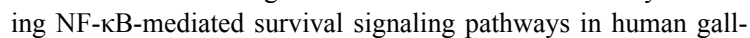
bladder cancer cells. Oncol Rep. 2015;33(4):1683-1690.

91. Vaitkiene P, Urbanaviciute R, Grigas P, Steponaitis G, Tamasauskas A, Skiriute D. Identification of astrocytoma blood serum protein profile. Cells. 2019;9(1). doi:10.3390/cells9010016

92. Zhou S, Zhu Y, Xu J, Tao R, Yuan S. Rare NF1 gene mutation in Chinese patient with neurofibromatosis type 1 and anaplastic astrocytoma. World Neurosurg. 2020;134:434-437. doi:10.1016/ j.wneu.2019.10.126

93. Martin R, Carvalho-Tavares J, Ibeas E, Hernandez M, RuizGutierrez V, Nieto ML. Acidic triterpenes compromise growth and survival of astrocytoma cell lines by regulating reactive oxygen species accumulation. Cancer Res. 2007;67 (8):3741-3751. doi:10.1158/0008-5472.CAN-06-4759

94. Martinelli S, Maggi M, Rapizzi E. Pheochromocytoma/paraganglioma preclinical models: which to use and why? Endocr Connect. 2020;9(12):R251-R260. doi:10.1530/EC-20-0472

95. Eisenhofer G, Pacak K, Maher ER, Young WF, de Krijger RR. Pheochromocytoma. Clin Chem. 2013;59(3):466-472. doi:10.1373/clinchem.2012.182246

96. Han H, Lim JW, Kim H. Lycopene inhibits activation of epidermal growth factor receptor and expression of cyclooxygenase-2 in gastric cancer cells. Nutrients. 2019;11(9):2113. doi:10.3390/nu11092113

97. Liu Y, Lu H, Dong Q, Hao X, Qiao L. Maslinic acid induces anticancer effects in human neuroblastoma cells mediated via apoptosis induction and caspase activation, inhibition of cell migration and invasion and targeting MAPK/ERK signaling pathway. AMB Express. 2020;10 (1):104. doi:10.1186/s13568-020-01035-1 
98. Villar VH, Vogler O, Barcelo F, et al. Oleanolic and maslinic acid sensitize soft tissue sarcoma cells to doxorubicin by inhibiting the multidrug resistance protein MRP-1, but not P-glycoprotein. J Nutr Biochem. 2014;25(4):429-438. doi:10.1016/j.jnutbio.2013.12.003

99. Parra A, Rivas F, Martin-Fonseca S, Garcia-Granados A, Martinez A. Maslinic acid derivatives induce significant apoptosis in b16f10 murine melanoma cells. Eur J Med Chem. 2011;46 (12):5991-6001. doi:10.1016/j.ejmech.2011.10.011

100. Medina-O’Donnell M, Rivas F, Reyes-Zurita FJ, et al. Semi-synthesis and antiproliferative evaluation of PEGylated pentacyclic triterpenes. Eur JMed Chem. 2016;118:64-78. doi:10.1016/j.ejmech.2016.04.016

101. Medina-O'Donnell M, Rivas F, Reyes-Zurita FJ, Martinez A, Lupianez JA, Parra A. Diamine and PEGylated-diamine conjugates of triterpenic acids as potential anticancer agents. Eur J Med Chem. 2018;148:325-336. doi:10.1016/j.ejmech.2018.02.044

102. Chouaib K, Delemasure S, Dutartre P, Jannet HB. Microwaveassisted synthesis, anti-inflammatory and anti-proliferative activities of new maslinic acid derivatives bearing 1,5- and 1,4-disubstituted triazoles. J Enzyme Inhib Med Chem. 2016;31 (sup2):130-147. doi:10.1080/14756366.2016.1193733

103. Sommerwerk S, Heller L, Kerzig C, Kramell AE, Csuk R. Rhodamine $\mathrm{B}$ conjugates of triterpenoic acids are cytotoxic mitocans even at nanomolar concentrations. Eur $J$ Med Chem. 2017;127:1-9. doi:10.1016/j.ejmech.2016.12.040

104. Serbian I, Siewert B, Al-Harrasi A, Csuk R. 2-O-(2-chlorobenzoyl) maslinic acid triggers apoptosis in A2780 human ovarian carcinoma cells. Eur J Med Chem. 2019;180:457-464. doi:10.1016/j.ejmech.2019.07.049

105. Siewert B, Csuk R. Membrane damaging activity of a maslinic acid analog. Eur J Med Chem. 2014;74:1-6. doi:10.1016/j. ejmech.2013.12.031

106. Pavel IZ, Danciu C, Oprean C, et al. In vitro evaluation of the antimicrobial ability and cytotoxicity on two melanoma cell lines of a benzylamide derivative of maslinic acid. Anal Cell Pathol. 2016;2016:2787623. doi:10.1155/2016/2787623

107. Skehan P, Storeng R, Scudiero D, et al. New colorimetric cytotoxicity assay for anticancer-drug screening. J Natl Cancer Inst. 1990;82(13):1107-1112. doi:10.1093/jnci/82.13.1107

108. Sommerwerk S, Heller L, Kuhfs J, Csuk R. Urea derivates of ursolic, oleanolic and maslinic acid induce apoptosis and are selective cytotoxic for several human tumor cell lines. Eur J Med Chem. 2016;119:1-16.

109. Peng F, Xiong L, Xie XF, Tang HL, Huang RZ, Peng C. Isoliquiritigenin derivative regulates $\mathrm{miR}-374 \mathrm{a} / \mathrm{BAX}$ axis to suppress triple-negative breast cancer tumorigenesis and development. Front Pharmacol. 2020;11:378. doi:10.3389/fphar.2020.00378

110. Peng F, Xiong L, Peng C. (-)-Sativan inhibits tumor development and regulates miR-200c/PD-L1 in triple negative breast cancer cells. Front Pharmacol. 2020;11:251. doi:10.3389/fphar.2020.00251

111. Peng F, Tang H, Du J, Chen J, Peng C. Isoliquiritigenin suppresses EMT-induced metastasis in triple-negative breast cancer through miR-200c/C-JUN/ formula: see text -catenin. Am J Chin Med. 2021;49(2):505-523. doi:10.1142/S0192415X21500233
112. Zhang J, Liu F, Zhang X. Inhibition of proliferation of SGC7901 and BGC823 human gastric cancer cells by ursolic acid occurs through a caspase-dependent apoptotic pathway. Med Sci Monit. 2019;25:6846-6854. doi:10.12659/MSM.916740

113. Sheng H, Sun H. Synthesis, biology and clinical significance of pentacyclic triterpenes: a multi-target approach to prevention and treatment of metabolic and vascular diseases. Nat Prod Rep. 2011;28(3):543-593.

114. Lozano-Mena G, Sánchez-González M, Parra A, Juan M, Planas J. Identification of gut-derived metabolites of maslinic acid, a bioactive compound from Olea europaea L. Mol Nutr Food Res. 2016;60(9):2053-2064.

115. Sánchez-González M, Colom H, Lozano-Mena G, Juan M, Planas J. Population pharmacokinetics of maslinic acid, a triterpene from olives, after intravenous and oral administration in rats. Mol Nutr Food Res. 2014;58(10):1970-1979.

116. de la Torre R, Carbó M, Pujadas M, et al. Pharmacokinetics of maslinic and oleanolic acids from olive oil - effects on endothelial function in healthy adults. A randomized, controlled, dose-response study. Food Chem. 2020;30:126676.

117. Wu DM, Zhao D, Li DZ, Xu DY, Chu WF, Wang XF. Maslinic acid induces apoptosis in salivary gland adenoid cystic carcinoma cells by Ca2+-evoked p38 signaling pathway. Naunyn Schmiedebergs Arch Pharmacol. 2011;383(3):321-330.

118. Tournier C, Hess P, Yang D, et al. Requirement of JNK for stress-induced activation of the cytochrome c-mediated death pathway. Science. 2000;288(5467):870-874.

119. Fan M, Goodwin M, Vu T, Brantley-Finley C, Gaarde W, Chambers T. Vinblastine-induced phosphorylation of Bcl-2 and $\mathrm{Bcl}-\mathrm{XL}$ is mediated by JNK and occurs in parallel with inactivation of the Raf-1/MEK/ERK cascade. J Biol Chem. 2000;275 (39):29980-29985.

120. Reynaud D, Pietras E, Barry-Holson K, et al. IL-6 controls leukemic multipotent progenitor cell fate and contributes to chronic myelogenous leukemia development. Cancer Cell. 2011;20(5):661-673.

121. Follin-Arbelet V, Torgersen ML, Naderi EH, Misund K, Sundan A, Blomhoff HK. Death of multiple myeloma cells induced by cAMP-signaling involves downregulation of Mcl-1 via the JAK/STAT pathway. Cancer Lett. 2013;335(2):323-331. doi:10.1016/j.canlet.2013.02.042

122. Ogata A, Chauhan D, Teoh G, et al. IL-6 triggers cell growth via the Ras-dependent mitogen-activated protein kinase cascade. J Immunol. 1997;159(5):2212-2221.

123. To K, Chan M, Leung W, et al. Constitutional activation of IL-6-mediated JAK/STAT pathway through hypermethylation of SOCS-1 in human gastric cancer cell line. Br J Cancer. 2004;91 (7):1335-1341.

\section{Publish your work in this journal}

Drug Design, Development and Therapy is an international, peerreviewed open-access journal that spans the spectrum of drug design and development through to clinical applications. Clinical outcomes, patient safety, and programs for the development and effective, safe, and sustained use of medicines are a feature of the journal, which has also been accepted for indexing on PubMed Central. The manuscript management system is completely online and includes a very quick and fair peer-review system, which is all easy to use. Visit http://www. dovepress.com/testimonials.php to read real quotes from published authors. 